\title{
Carbon stocks and fluxes in the high latitudes: using site-level data to evaluate Earth system models
}

Sarah E. Chadburn ${ }^{1,2}$, Gerhard Krinner ${ }^{3}$, Philipp Porada ${ }^{4,5}$, Annett Bartsch ${ }^{6,7}$, Christian Beer $^{4,5}$, Luca Belelli Marchesini $^{8,9}$, Julia Boike ${ }^{10}$, Altug Ekici ${ }^{11}$, Bo Elberling ${ }^{12}$, Thomas Friborg $^{12}$, Gustaf Hugelius ${ }^{13}$, Margareta Johansson ${ }^{14}$, Peter Kuhry ${ }^{13}$, Lars Kutzbach ${ }^{15}$, Moritz Langer ${ }^{10}$, Magnus Lund ${ }^{16}$, Frans-Jan W. Parmentier ${ }^{17,20}$, Shushi Peng ${ }^{3,18}$, Ko Van Huissteden ${ }^{9}$, Tao Wang ${ }^{19}$, Sebastian Westermann ${ }^{20}$, Dan Zhu ${ }^{21}$, and Eleanor J. Burke ${ }^{22}$

${ }^{1}$ University of Leeds, School of Earth and Environment, Leeds LS2 9JT, UK

${ }^{2}$ University of Exeter, College of Engineering, Mathematics and Physical sciences, Exeter EX4 4QF, UK

${ }^{3}$ CNRS, University Grenoble Alpes, IGE, Grenoble, France

${ }^{4}$ Department of Environmental Science and Analytical Chemistry, Stockholm University, 10691 Stockholm, Sweden

${ }^{5}$ Bolin Centre for Climate Research, Stockholm University, 10691 Stockholm, Sweden

${ }^{6}$ Department of Geodesy and Geoinformation, Vienna University of Technology, Vienna, Austria

${ }^{7}$ Cryosphere \& Climate, Austrian Polar Research Institute, Vienna, Austria

${ }^{8}$ School of Natural Sciences, Far Eastern Federal University, Vladivostok, Russia

${ }^{9}$ Department of Earth Sciences, Vrije Universiteit (VU), Amsterdam, the Netherlands

${ }^{10}$ Alfred Wegener Institute, Helmholtz Centre for Polar and Marine Research (AWI), 14473 Potsdam, Germany

${ }^{11}$ Uni Research Climate and Bjerknes Centre for Climate Research, Bergen, Norway

${ }^{12}$ Center for Permafrost (CENPERM), Department of Geosciences and Natural Resource Management, University of Copenhagen, Copenhagen, Denmark

${ }^{13}$ Department of Physical Geography, Stockholm University, 10691 Stockholm, Sweden

${ }^{14}$ Department of Physical Geography and Ecosystem Science, Lund University, Sölvegatan 12, 22362 Lund, Sweden

${ }^{15}$ Institute of Soil Science, Center for Earth System Research and Sustainability, Universität Hamburg, Hamburg, Germany

${ }^{16}$ Department of Bioscience, Arctic Research Center, Aarhus University, Frederiksborgvej 399, 4000 Roskilde, Denmark

${ }^{17}$ Department of Arctic and Marine Biology, UiT - The Arctic University of Norway, Troms $\varnothing$, Norway

${ }^{18}$ Sino-French Institute for Earth System Science, College of Urban and Environmental Sciences, Peking University, Beijing 100871, China

${ }^{19}$ Key Laboratory of Alpine Ecology and Biodiversity, Institute of Tibetan Plateau Research and Center for Excellence in Tibetan Plateau Earth Sciences, Chinese Academy of Sciences, Beijing 100085, China

${ }^{20}$ University of Oslo, Department of Geosciences, P.O. Box 1047 Blindern, 0316 Oslo, Norway

${ }^{21}$ Laboratoire des Sciences du Climat et de l'Environnement, LSCE CEA CNRS UVSQ, Gif-Sur-Yvette, France

${ }^{22}$ Met Office Hadley Centre, Fitzroy Road, Exeter EX1 3PB, UK

Correspondence to: Sarah E. Chadburn (s.e.chadburn@exeter.ac.uk)

Received: 17 May 2017 - Discussion started: 31 May 2017

Revised: 2 September 2017 - Accepted: 5 September 2017 - Published: 17 November 2017 
Abstract. It is important that climate models can accurately simulate the terrestrial carbon cycle in the Arctic due to the large and potentially labile carbon stocks found in permafrost-affected environments, which can lead to a positive climate feedback, along with the possibility of future carbon sinks from northward expansion of vegetation under climate warming. Here we evaluate the simulation of tundra carbon stocks and fluxes in three land surface schemes that each form part of major Earth system models (JSBACH, Germany; JULES, UK; ORCHIDEE, France). We use a site-level approach in which comprehensive, high-frequency datasets allow us to disentangle the importance of different processes. The models have improved physical permafrost processes and there is a reasonable correspondence between the simulated and measured physical variables, including soil temperature, soil moisture and snow.

We show that if the models simulate the correct leaf area index (LAI), the standard C3 photosynthesis schemes produce the correct order of magnitude of carbon fluxes. Therefore, simulating the correct LAI is one of the first priorities. LAI depends quite strongly on climatic variables alone, as we see by the fact that the dynamic vegetation model can simulate most of the differences in LAI between sites, based almost entirely on climate inputs. However, we also identify an influence from nutrient limitation as the LAI becomes too large at some of the more nutrient-limited sites. We conclude that including moss as well as vascular plants is of primary importance to the carbon budget, as moss contributes a large fraction to the seasonal $\mathrm{CO}_{2}$ flux in nutrient-limited conditions. Moss photosynthetic activity can be strongly influenced by the moisture content of moss, and the carbon uptake can be significantly different from vascular plants with a similar LAI.

The soil carbon stocks depend strongly on the rate of input of carbon from the vegetation to the soil, and our analysis suggests that an improved simulation of photosynthesis would also lead to an improved simulation of soil carbon stocks. However, the stocks are also influenced by soil carbon burial (e.g. through cryoturbation) and the rate of heterotrophic respiration, which depends on the soil physical state. More detailed below-ground measurements are needed to fully evaluate biological and physical soil processes. Furthermore, even if these processes are well modelled, the soil carbon profiles cannot resemble peat layers as peat accumulation processes are not represented in the models.

Thus, we identify three priority areas for model development: (1) dynamic vegetation including (a) climate and (b) nutrient limitation effects; (2) adding moss as a plant functional type; and an (3) improved vertical profile of soil carbon including peat processes.

\section{Introduction}

Land areas in northern high latitudes may represent a net source or a net sink of carbon to the atmosphere in the future, and there is not yet a consensus as to which of the two is more likely (Cahoon et al., 2012; Hayes et al., 2011). This is not because it is likely to be small: on a pan-Arctic scale we could see anything between a net emission of over $100 \mathrm{GtC}$ or a net sink of up to $60 \mathrm{GtC}$ by the end of this century (Schuur et al., 2015; Qian et al., 2010). To put this into context, the remaining emissions budget in order to stabilise climate warming below $2{ }^{\circ} \mathrm{C}$ above pre-industrial levels is less than $250 \mathrm{GtC}$ from 2017 on (Peters et al., 2015). Thus, it is very important to reduce uncertainty in the northern high latitude carbon cycle. The uncertainty comes largely from the representation of these processes in Earth system models (ESMs), which are our main tool for future climate projections.

The potential for large carbon emissions comes from the large quantities of old carbon that are frozen into permafrost, protected from decomposition under the current cold climate. Around $800 \mathrm{Gt}$ of carbon is stored in permanently frozen soils (Hugelius et al., 2014). If the permafrost thaws, this carbon may decompose and be released into the atmosphere (Burke et al., 2012, 2013; Koven et al., 2015; Schneider von Deimling et al., 2012, 2015; MacDougall and Knutti, 2016). Conversely, the increased vegetation growth that is already taking place in the Arctic under climate warming (Tucker et al., 2001; Tape et al., 2006) could result in a net uptake of carbon from the atmosphere (Quegan et al., 2011; Qian et al., 2010). It should be noted, however, that in some areas Arctic vegetation growth is not increasing but rather "browning" (Epstein et al., 2016).

The representations of both permafrost carbon and Arctic vegetation in ESMs are not well developed. Some models now include a vertical representation of soil carbon, which allows the frozen carbon in permafrost to be included (Koven et al., 2009, 2013; Schaphoff et al., 2013; Burke et al., 2017), but most do not yet represent important mechanisms of carbon storage and release, such as sedimentation, thermokarst formation and a proper representation of cryoturbation (Schneider von Deimling et al., 2015; Beer, 2016), although sedimentation is included in (Zhu et al., 2016). There is also a growing consensus that the chemical decomposition models used in ESMs are not adequate to represent microbial processes (Wieder et al., 2013; Xenakis and Williams, 2014). Vegetation models also, for the most part, do not include the appropriate high-latitude vegetation types, and those models that have dynamic vegetation are lacking in processes that are essential determinants of vegetation dynamics, such as nutrient limitation and interactions with soil (Wieder et al., 2015).

In this paper we assess the ability of the land surface components from three ESMs to represent the carbon stocks and fluxes observed at tundra sites, identifying the processes that 
have the greatest impact on the uncertainty. These processes are therefore priorities for future model development. Observational studies in tundra environments have shown that carbon dynamics are sensitive to physical conditions (Lund et al., 2012; Cannone et al., 2016; Pirk et al., 2017); thus, we first assess the ability of the models to capture the mean physical state of the system and the differences between sites, specifically in terms of snow depth, soil temperature, soil moisture and active-layer depth. Secondly, soil carbon stocks are evaluated against measured soil carbon profiles, assessing the main causes of biases in the models. Half-hourly net ecosystem exchange (NEE) data from eddy flux towers are used to evaluate the simulated carbon fluxes, comparing the models directly against observations before analysing the relationships between ecosystem carbon fluxes and different driving variables. We also consider the impacts of other controlling factors such as nutrient limitation and mosses, whose importance has been identified in previous studies (Atkin, 1996; Uchida et al., 2009).

This is a synthesis from the recently concluded EU project PAGE21 (Changing Permafrost in the Arctic and its Global Effects in the 21st century), evaluating the models that took part in the project (described in Sect. 2.2, below) at the five PAGE21 primary sites, which are all located in Arctic permafrost regions, specifically Siberia, Sweden, Svalbard and Greenland. After the site-level evaluation of physical processes by (Ekici et al., 2015), this evaluation of carbon cycle processes continues site-level model evaluation efforts. The sites are described in detail in Sect. 2.3.

\section{Methods}

This study takes three different angles: (1) comparison with observed indicators; (2) comparison of processes between models and (3) comparison of geographical conditions (e.g. vegetation, permafrost) between sites. The structure of the methods section is as follows: first describing the observational indicators used (Sect. 2.1), second the processes represented in the models (Sect. 2.2) and third the conditions at the sites (Sect. 2.3). Lastly, details of the simulation set-up and forcing data are given in Sect. 2.4.

\subsection{Evaluation data}

\subsubsection{Carbon dioxide flux}

Eddy covariance half-hourly $\mathrm{CO}_{2}$ flux data and related meteorological variables used in this study are archived in the PAGE21 fluxes database (http://www.europe-fluxdata.eu/ page21), which is part of the European Fluxes Database Cluster.

Flux post-processing was performed consistently for all the sites following the protocol applied for the FLUXNET2015 data release (http://fluxnet.fluxdata.org/ data/fluxnet2015-dataset), with customised choices of the processing options. The applied scheme included the following: (i) a quality assessment and quality control procedure over single variables aimed at detecting implausible values or incorrect time stamps (e.g. by comparing patterns of potential and observed downward shortwave radiation at a given location); (ii) the computation of NEE by adding the $\mathrm{CO}_{2}$ flux storage term calculated from a single $\mathrm{CO}_{2}$ concentration measurement point (at the top of the flux tower) and assuming a vertically uniform concentration field; (iii) the de-spiking of NEE based on (Papale et al., 2006) using a threshold value $(z=5)$; (iv) NEE filtering according to an ensemble of friction velocity $\left(u^{*}\right)$ thresholds obtained with bootstrapping following the methods of (Barr et al., 2013) and (Papale et al., 2006) and selection of a $u^{*}$ threshold, different for each year, based on the highest model efficiency (Nash-Sutcliffe); (vi) the gap-filling of NEE time series with the marginal distribution sampling method (Reichstein et al., 2005).

Finally, NEE was partitioned into the gross primary productivity (GPP) and ecosystem respiration $\left(R_{\text {eco }}\right)$ components using a semi-empirical model based on a hyperbolic light-response curve fitted to daytime NEE data (Lasslop et al., 2010). The years of data available for each site are given in Table $\mathrm{S} 1$.

\subsubsection{Soil carbon profiles}

Typical soil profiles with data on soil organic carbon content were generated for each site. Based on extensive field campaigns in each study area, individual pedons for representative landscape and soil types were combined and harmonised. In brief, soils were classified and sampled from open soil pits dug down to the permafrost. Permafrost samples were collected through manual coring into the permafrost at the bottom of the soil pit. In most cases, soils were sampled to a depth of $1 \mathrm{~m}$. The harmonised soil profiles were generated by averaging several soil pedons per landscape type at a $1 \mathrm{~cm}$ depth resolution. For more detailed descriptions of field sampling and laboratory procedures, see Palmtag et al. (2015) and Siewert et al. $(2015,2016)$. Top $1 \mathrm{~m}$ total soil carbon values were calculated from a weighted average of different typical profiles, based on the fractional coverage of landscape types in the footprint area of the flux towers.

\subsubsection{Snow depth}

Snow depth was recorded using automatic sensors (except Abisko, where it is manual). Snow depth from the Abisko mire (Storflaket) was recorded manually monthly (Johansson et al., 2013). Snow depth at Samoylov and Bayelva was recorded hourly, and for Zackenberg 3-hourly (using sonic range and laser sensors). Snow depth at Kytalyk was measured by means of a $70 \mathrm{~cm}$ vertical profile made of thermistors spaced every $5 \mathrm{~cm}(2.5 \mathrm{~cm}$ between 0 and $10 \mathrm{~cm}$ height from the ground). Data were logged every $2 \mathrm{~h}$ and the snow- 
air interface level was identified by analysing the profile patterns with a MATLAB $\odot$ routine calibrated to search for deviations between consecutive resistance readings above a given threshold. Years used for each site are given in Table S1.

\subsubsection{Soil temperature}

For Samoylov, Bayelva, Kytalyk and Zackenberg, soil temperature was recorded hourly using thermistors (Kytalyk setup described in van der Molen et al., 2007). Ground temperatures for Abisko mire were recorded at the Storflaket mire, at boreholes cased with plastic tubes and instrumented with HOBO loggers U12 (industry, four channels) together with HOBO soil temperature sensors (Johansson et al., 2011). The years used for each site are given in Table S1.

\subsubsection{Soil moisture}

Continuous soil moisture measurements are only available for Bayelva, Samoylov and Zackenberg. At Samoylov and Bayelva, hourly volumetric soil water content was recorded (using time domain reflectometry). At Zackenberg soil moisture was measured using permanently installed ML2x ThetaProbes (Lund et al., 2014). Years used for each site are given in Table S1. Indicative soil moisture levels for Abisko mire were collected from May to October 2015 (Pedersen et al., 2017), measured manually as volumetric soil water content integrated over $0-6 \mathrm{~cm}$ depth using a handheld ML2x ThetaProbe (Delta-T Devices Ltd., Cambridge, UK). Soil moisture was measured five times in each plot and averages were subsequently used.

\subsubsection{Active-layer depth}

Active-layer depth was measured at Circumpolar Active Layer Monitoring (CALM) grids at most of the sites. At Bayelva there is no CALM grid; thus, the active layer was estimated from soil temperature measurements and is given as an indicative value. Active-layer thickness monitoring is determined by mechanical probing. A $1 \mathrm{~cm}$ diameter graduated steel rod is inserted into the soil to the depth of resistance to determine the active-layer thickness (Åkerman and Johansson, 2008) according to the CALM standard.

\subsubsection{Leaf area index}

Leaf area index was taken from the MODIS product (MODIS15A2, 2016) for the closest coordinates to the sites. This product has been successfully applied to tundra sites (Cristóbal et al., 2017). It was evaluated by (Cohen et al., 2006), who found an RMSE of 0.28 at a tundra site. There are, however, still considerable uncertainties in using this data product (see Sect. 3.6.1).

\subsubsection{GPP per unit leaf area}

This was calculated using the partitioned GPP from the eddy covariance data (Sect. 2.1.1), averaged daily and taken on the same day as the values from the MODIS LAI product (Sect. 2.1.7). Note that there are no time-resolved GPP values for Bayelva due to insufficient data. The extracted GPP values were divided by the appropriate LAI estimates and the resulting values were collected for all sites and binned into intervals of air temperature $\left(1.5^{\circ} \mathrm{C}\right)$ and shortwave radiation $\left(20 \mathrm{Wm}^{-2}\right)$, for which the mean and standard deviation were then calculated (shown in Fig. 9).

\subsection{Model description}

The three models studied here are JSBACH (Jena Scheme for Biosphere-Atmosphere Coupling in Hamburg; Raddatz et al., 2007; Brovkin et al., 2009), JULES (Joint UK Land Environment Simulator; Best et al., 2011; Clark et al., 2011) and ORCHIDEE (ORganizing Carbon and Hydrology In Dynamic Ecosystems Environment; Krinner et al., 2005). These are all land surface components of major ESMs (JSBACH: MPI-ESM; JULES: UKESM; ORCHIDEE: IPSL). Key features are summarised in Table 1.

These models can be run in a coupled mode within the ESM, or, as here, they can be run as stand-alone models forced by observed meteorology. The models are run as a gridded set of points for large-scale simulations, and they can also be run for single points, as in this study. Each model had some development of high-latitude processes during the PAGE21 project, and model developments have also been ongoing since the conclusion of the project in late 2015.

All the models simulate vertical fluxes of water, heat and carbon between the atmosphere, the vegetation and the soil. Of relevance to permafrost physics, the models simulate a dynamic snowpack by means of a multilayer snow scheme and the freezing and thawing of soil (Ekici et al., 2014; Gouttevin et al., 2012a; Wang et al., 2013; Best et al., 2011). All models use a vertical discretisation of soil thermal and hydrological fluxes, with differing resolutions (see Appendix Table A2). JSBACH has the lowest-resolution soil, with only five layers in the top $10 \mathrm{~m}$ (Hagemann and Stacke, 2015), although in this latest version it is extended to $50 \mathrm{~m}$ depth with additional layers. ORCHIDEE and JULES also simulate an extra thermal-only column at the base of the hydrological column to represent bedrock (Chadburn et al., 2015a).

Soil thermal and hydrological properties in both JULES and ORCHIDEE have been adapted to allow better representation of organic soils, whereas in JSBACH only mineral soil properties are represented. However, JSBACH additionally simulates a moss and/or lichen layer at the surface with dynamic moisture contexts and thermal properties (Porada et al., 2016), which physically represents the surface organic layer. Organic soil properties in JULES are described in Chadburn et al. (2015a). In ORCHIDEE the scheme fol- 
lows (Lawrence and Slater, 2008), using the observationbased soil carbon map from (Hugelius et al., 2014).

Soil carbon is represented by a multi-pool scheme in all the models, with inputs from vegetation, and decomposition rates depending on soil temperature, soil moisture and intrinsic turnover times of different pools (Goll et al., 2015; Clark et al., 2011). Both ORCHIDEE and JULES represent a vertical profile of soil carbon (discretised in line with the soil hydrology), including cryoturbation mixing (Koven et al., 2009; Burke et al., 2017). JSBACH, however, represents only a single layer, with decomposition rates determined by conditions in the upper layer of soil.

None of the models simulate nitrogen or other nutrients. Vegetation growth and productivity is therefore only determined by soil moisture and atmospheric forcing data, with no nutrient limitation. Different land cover types are represented in the models by surface tiles, which can vary in fractional cover. In JULES, a dynamic vegetation model is run with nine competing plant functional types (PFTs) (Harper et al., 2016), whereas in the other models, vegetation is fixed, but with dynamic phenology. ORCHIDEE has 13 PFTs but there is no specific high-latitude PFT in the version used here; thus, C3 grasses are prescribed for these sites. In JS$\mathrm{BACH}$ there are 20 PFTs (including crop and pasture) and for these sites a tundra PFT is used, which is similar to C3 grass but with reduced Vcmax (maximum rate of carboxylation in leaves). In JSBACH there is also a dynamic moss model simulating moss photosynthesis and respiration, as in the model described by (Porada et al., 2013). This model represents both mosses and lichens by one plant functional type with average physiological properties. In the version used here, the moss carbon fluxes are not yet fully coupled into the JSBACH carbon cycle; thus, the moss carbon fluxes are considered separately in the analysis that follows.

For more details of the soil and vegetation configuration see Sect. 2.4 and the Appendix.

\subsection{Site descriptions}

The sites represent a range of climatological and biogeophysical conditions across the tundra. Abisko is the warmest site, with sporadic permafrost, followed by Bayelva, which is a high Arctic maritime site (on Svalbard), and Zackenberg, which is a maritime site in Greenland (colder than Bayelva). Samoylov and Kytalyk have a continental Siberian climate and the coldest mean annual temperatures. The landscapes differ between sites, which can influence the permafrost and carbon dynamics, for example through the impact of topography on snow distribution and hydrology. The following sections provide a short description of each study area, and the important climatic and permafrost variables are given in Table 2 .

At all sites there has been some tendency towards air temperature warming, which in many cases is accompanied by warming or thawing of permafrost (Callaghan et al., 2010;
Christiansen et al., 2010; Parmentier et al., 2011; Boike et al., 2013; Lund et al., 2014; Abermann et al., 2017).

\subsubsection{Abisko}

The Abisko site is located in the Torneträsk catchment in northernmost Sweden. According to (Brown et al., 1998), the Abisko area lies within the zone of discontinuous permafrost. However, with the observed permafrost degradation during the last decades (Åkerman and Johansson, 2008; Johansson et al., 2011), the area is now more characteristic of the sporadic permafrost zone. Permafrost is widespread in the mountains (Ridefelt et al., 2008), but at lower elevations permafrost is only found in peat mires (Johansson et al., 2006). Data from three sites from the Torneträsk catchment (within an area of $10 \mathrm{~km}$ ) have been used for this study. The principal sites are Storflaket and Stordalen peat mires. The active-layer measurements and the ground temperatures are monitored at the Storflaket site (Akerman and Johansson, 2008; Johansson et al., 2011) and the carbon monitoring, including the eddy covariance measurement, is carried out at the Stordalen site. These two mire sites are very similar in terms of climate, soil profile and permafrost characteristics. The footprint of the eddy covariance tower is characterised by wet fen with no permafrost present and vegetation dominated by tall graminoids (Jammet et al., 2015, 2017). For comparison, additional soil temperature data from a mineral soil site at the Abisko Scientific Research Station, which is not underlain by permafrost, are included.

\subsubsection{Bayelva (Svalbard)}

The study site is located in the high-Arctic Bayelva River catchment area, close to Ny-Ålesund on Spitsbergen island in the Svalbard archipelago. The area is characterised by maritime continuous permafrost. In bioclimatic terms the area represents a semi-desert ecosystem (Uchida et al., 2009). Vegetation includes low vascular plants (mainly grass, sedge, catchfly, saxifrage and willow), mosses and lichens (Ohtsuka et al., 2006; Uchida et al., 2006). The ground is mostly bedrock but is partly covered by a mixture of sediments. The study site is located on permafrost patterned ground mainly consisting of non-sorted soil circles or mud boils, with around $60 \%$ vegetation cover. The eddy covariance measurements were conducted on Leirhaugen hill, and additional meteorological observations and ground temperature measurements are continuously conducted at the Bayelva soil and climate monitoring station (Boike et al., 2003, 2008a; Roth and Boike, 2001) $100 \mathrm{~m}$ away. Over the past decade the Bayelva catchment has been the focus of intensive investigations on soil and permafrost conditions (Roth and Boike, 2001; Boike et al., 2008a; Westermann et al., 2010, 2011) and the surface energy balance (Boike et al., 2003; Westermann et al., 2009). Details of the measurements are provided in Westermann et al. (2009) and Lüers et al. (2014). 


\subsubsection{Kytalyk}

The Kytalyk site is located in the Kytalyk reserve, $28 \mathrm{~km}$ northwest of the village of Chokurdakh in the Republic of Sakha (Yakutia), Russian Federation. The site is located between the East Siberian Sea and the transition zone between taiga and tundra. The area is underlain by continuous permafrost. The measurement site is located at the bottom of a drained former thermokarst lake, and the site is bordered by the edge of the present river floodplain. Both on the floodplain and at the lake bottom, a network of ice wedge polygons occurs, in general of the low-centred type. These form a mosaic of low plateaus and ridges dominated by Betula nana and diffuse drainage channels covered with a meadowlike vegetation of Eriophorum angustifolium and Carex sp. There is also hummocky Sphagnum with low Salix dwarf shrubs, polygon ponds covered with mosses and Comarum palustre, deeper ponds in which ice wedges have thawed, and drier areas covered with Eriophorum vaginatum tussocks. The soils generally have a $10-40 \mathrm{~cm}$ organic top layer overlying silt. The eddy covariance tower is located at a distance of ca. $200 \mathrm{~m}$ from the research station buildings (van der Molen et al., 2007). The tower footprint covers a wet northwestern and southeastern sector dominated by Sphagnum and ponds, while the northeastern and southwestern sectors have drier vegetation types.

\subsubsection{Samoylov}

Samoylov Island lies within one of the main river channels in the southern part of the Lena river delta in northern Yakutia. The landscape on Samoylov Island, and in the delta as a whole, has generally been shaped by water through erosion and sedimentation (Fedorova et al., 2015), and by thermokarst processes (Morgenstern et al., 2013). Continuous cold permafrost underlies the study area to between about 400 and $600 \mathrm{~m}$ below the surface. The terrace where the study site is situated is covered in low-centred ice wedge polygons, with water-saturated soils or small ponds in the polygon centres. The mineral soil is generally sandy loam, underlain by silty river deposits, with a $\sim 30 \mathrm{~cm}$ thick organic layer (Boike et al., 2013). Vegetation in the polygon centres and at the edge of ponds is dominated by sedges and mosses, and at the polygon rims various mesophytic dwarf shrubs, forbs and mosses dominate (Kutzbach et al., 2007). It is estimated that moss contributes around $40 \%$ to the total photosynthesis (Kutzbach et al., 2007). Detailed information concerning the climate, permafrost, land cover, vegetation and soil characteristics of Samoylov Island can be found in (Boike et al., 2013) and (Morgenstern et al., 2013). Analysis of the energy balance for the site is found in Boike et al. (2008b) and Langer et al. (2011a, b).

\subsubsection{Zackenberg}

The Zackenberg study site is located near the Zackenberg Research Station within the Northeast Greenland National Park, within the continuous permafrost zone. High mountains surround the Zackenberg valley to the west, east and north, with a fjord to the south, and snow cover is characterised by large interannual variability (Pedersen et al., 2016). Water availability is thus regulated by topography and snow distribution patterns. Most vegetation in the Zackenberg valley is located below $300 \mathrm{~m}$ a.s.l., where the lowland is dominated by noncalcareous sandy fluvial sediments (Elberling et al., 2008), and peat soils have limited spatial coverage (Palmtag et al., 2015). The study site is located within a Cassiope tetragona tundra heath, dominated by $C$. tetragona, Dryas integrifolia and Vaccinium uliginosum, with patches of mosses. Several studies on soil and permafrost (Palmtag et al., 2015; Westermann et al., 2015), surface energy balance (Lund et al., 2014; Stiegler et al., 2016; Lund et al., 2017) and carbon exchange (Mastepanov et al., 2008; Lund et al., 2012; Elberling et al., 2013) have been published based on data from this site. A rich dataset is available from this site through the extensive, cross-disciplinary Greenland Ecosystem Monitoring programme (www.g-e-m.dk).

\subsection{Simulation set-up}

The sites were represented in all the models by a single vertical column, although there was some horizontal representation by means of tiling approaches (see model description, Sect. 2.2). The models were run in the most up-to-date configurations, including new permafrost-relevant model developments where available. Variables were output at hourly and/or daily resolutions.

The meteorological driving data were prepared using observations from the site combined with reanalysis data for the grid cell containing the site. For the period 1901-1979, Water and Global Change forcing data (WFD) were used (Weedon et al., 2011). Data are provided at half-degree resolution for the whole globe at 3-hourly time resolution from 1901 to 2001. For the period 1979-2014, WATCH-ForcingData-ERA-Interim (WFDEI) was used (Weedon, 2013). For the time periods in which observed data were available, correction factors were generated by calculating monthly biases relative to the WFDEI data. These corrections were then applied to the time series from 1979 to 2014 of the WFDEI data. The WFD before 1979 were then corrected to match these data and the two datasets were joined at 1979 to provide gap-free 3-hourly forcing from 1901 to 2014. Local meteorological station observations were used for all variables except snowfall, which was estimated from the observed snow depth by treating increases in snow depth as snowfall events with an assumed snow density (see Appendix). These reconstructions were then used to provide correction factors to WFDEI and WFD. This leads to a more realistic snow depth 
in the model than using direct precipitation measurements, which are less precise due to wind effects and the difficulty of accurately measuring snowfall. However, the local precipitation measurements were still used for rainfall, as this is much more reliable, with a potential undercatch of only around $10 \%$ (Yang et al., 2005). For Abisko, meteorological data from the research station were used but additionally corrected by scaling the snowfall according to the ratio of monthly snow depths at the mire vs. the research station (snow depth was only measured monthly at Storflaket mire), and a reduction of $1{ }^{\circ} \mathrm{C}$ in air temperature. Even with these corrections, there is still considerable uncertainty in precipitation forcing, particularly the snowfall, so in order to test the impact of this, two of the models (JULES and JSBACH) performed two additional sets of simulations, with snowfall increased and reduced by $50 \%$.

Spin-up was performed as consistently as possible between the models, using the meteorological forcing from 1901 to 1930. Years were selected at random from this 30 -year period and the models were run for 10000 years with pre-industrial $\mathrm{CO}_{2}$ levels $(1850,286 \mathrm{ppm})$, followed by 50 years with changing $\mathrm{CO}_{2}$ levels (1851-1900). The model state at the end of this spin-up period was taken as the initial state for the main run (1 January 1901 to 31 December 2013). For JSBACH, there was an initial 50 years of hydrological spin-up before the main spin-up, with the permafrost impact on hydrology switched off, to allow the water to form a realistic profile (permafrost layers are impermeable and thus unrealistic initial conditions could otherwise be preserved). For JSBACH, the long spin-up was also between 7000 and 8000 years rather than 10000 since in this model there is no vertical representation of soil carbon, and therefore the soil carbon pools equilibrate much more quickly and had reached a steady state after 7000-8000 years. The $\mathrm{CO}_{2}$ forcing data are from (Meinshausen et al., 2011).

The soil parameters in the models were set up to represent each site as closely as possible (see Appendix and Table A1). These drew from literature values, a PAGE21 deliverable "catalogue of physical parameters", and field experience. (Note that the soil carbon profiles described in Sect. 2.1.2 were not used for this).

Vegetation was prescribed in ORCHIDEE and JSBACH. Since these are tundra sites, JSBACH used a tundra PFT ( $100 \%$ coverage), which is similar to $\mathrm{C} 3$ grass but with reduced Vcmax. ORCHIDEE prescribed C3 grass (100\% coverage) as there is no tundra PFT in this model version. JULES was run with dynamic vegetation using nine PFTs (Harper et al., 2016), which do not include any tundra PFTs. All nine PFTs prognostically determine their coverage according to the environmental conditions, and they are all allowed to compete for space. In practice, only the $\mathrm{C} 3$ grass PFT is able to grow at these sites.

Some experiments were performed to separate the impacts of different processes. ORCHIDEE was run with and without vertical mixing of soil carbon. JSBACH carbon fluxes were analysed with and without an additional contribution from a new moss photosynthesis scheme. In JULES, an extra set of simulations was performed with fixed vegetation to compare with the dynamic vegetation scheme.

\section{Results and discussion}

The carbon dynamics are intrinsically linked to the physical state of the system (for example, determining the rate of soil carbon decomposition). Therefore, we start by assessing the snowpack, soil temperature, soil moisture and active-layer thickness in all three models. The model physics has also been evaluated in detail in previous publications (Ekici et al., 2015, 2014; Chadburn et al., 2015a; Porada et al., 2016) and is thus kept short here. In these studies, representing organic soil was identified as a key influence on the simulation of soil physics, and following this we compare organic with mineral soils in our analysis. We then evaluate the soil carbon stocks and the ecosystem $\mathrm{CO}_{2}$ fluxes, and we analyse the $\mathrm{CO}_{2}$ fluxes in detail. The fluxes depend on every part of the system and therefore all of the preceding analysis contributes to our understanding of the carbon dynamics at these sites.

\subsection{Snow}

The seasonal cycle of snow depth is shown in Fig. 1. It depends strongly on the snowfall driving data. Since the snowfall was back-calculated from the snow depth, the accumulation period should match well with observations. There is still some variation due to the fresh snow density in the models (which can differ from both the assumed density in making the driving data and between the models), and furthermore the compaction of the snow is dependent on the model process representation and physical conditions. Nonetheless, for the most part the models make a reasonable simulation of the snowpack accumulation and compaction, with the exception of Abisko, where the models are all biased high. Here, snow inputs are particularly uncertain as no high-resolution time series of snow depth are available (unlike the other sites). We performed a sensitivity study to test the impact of uncertainties or variability in snow depth on the simulated carbon cycle processes. In this study, a reduction of $50 \%$ in snowfall allows the models to simulate a realistic snow depth at Abisko - see the Supplement. The impacts on soil carbon stocks and fluxes are fairly small, however (between 0.2 and $10 \%$; Figs. S7 and S8).

During the melting season the models are less accurate than during accumulation, with the snow often melting too early, by up to 25 days in the most extreme case. Our method of back-calculating snowfall from snow depth may miss some snowfall events during the melt season. There are also many other potential influences such as albedo effects, snowvegetation interactions and the influence of wind-blown sediment. For example, the vegetation in the models is quite 
Table 1. Key features of the land surface models used in this study.

\begin{tabular}{llll}
\hline Process & JSBACH & JULES & ORCHIDEE \\
\hline PFTs & 20 & $9(+4$ crop/pasture $)$ & 13 \\
PFT that grows/is used & Tundra & C3 grass & C3 grass \\
Dynamic vegetation & No & Yes & No \\
Dynamic phenology & Yes & Yes & Yes \\
Nutrient limitation & No & No & No \\
Soil carbon & One layer & Multilayer & Multilayer \\
Soil carbon mixing & No & Yes & Yes \\
Deep soil respiration & None & Suppressed & Not suppressed \\
Soil latent heat & Yes & Yes & Yes \\
Snow & Multilayer & Multilayer & Multilayer \\
\hline
\end{tabular}

Table 2. Key climatic and physical variables at the sites.

\begin{tabular}{lrrrrr}
\hline & Abisko & Bayelva & Kytalyk & Samoylov & Zackenberg \\
\hline Latitude & 68.35 & 78.92 & 70.83 & 72.22 & 74.5 \\
Longitude & 19.05 & 11.93 & 147.5 & 126.28 & -20.6 \\
Elevation & $385 \mathrm{~m}$ a.s.1. & $25 \mathrm{~m}$ a.s.l. & $10 \mathrm{~m}$ a.s.l. & $6 \mathrm{~m}$ a.s.l. & $40 \mathrm{~m}$ a.s.l. \\
Mean annual air temp. & $-0.6^{\circ} \mathrm{C}$ & $-5^{\circ} \mathrm{C}$ & $-10.5^{\circ} \mathrm{C}$ & $-12.5^{\circ} \mathrm{C}$ & $-9^{\circ} \mathrm{C}$ \\
Max. monthly air temp. & $11^{\circ} \mathrm{C}$ & $5^{\circ} \mathrm{C}$ & $10^{\circ} \mathrm{C}$ & $10^{\circ} \mathrm{C}$ & $6.5^{\circ} \mathrm{C}$ \\
Min. monthly air temp. & $-11^{\circ} \mathrm{C}$ & $-13^{\circ} \mathrm{C}$ & $-34^{\circ} \mathrm{C}$ & $-33^{\circ} \mathrm{C}$ & $-20^{\circ} \mathrm{C}$ \\
Annual precipitation & $350 \mathrm{~mm}$ & $400 \mathrm{~mm}$ & $230 \mathrm{~mm}$ & $\sim 190 \mathrm{~mm}$ & $260 \mathrm{~mm}$ \\
Fraction as snow & $\sim 40 \%$ & $\sim 75 \%$ & $\sim 50 \%$ & $\sim 30 \%$ & $\sim 85 \%$ \\
Typical snow depth & $0.1 \mathrm{~m}$ & $0.5-0.8 \mathrm{~m}$ & $0.2-0.4 \mathrm{~m}$ & $0.2-0.4 \mathrm{~m}$ & $0.1-1.3 \mathrm{~m}$ \\
Active-layer depth & $0.55-1.2 \mathrm{~m}$ & $1-2 \mathrm{~m}$ & $0.25-0.5 \mathrm{~m}$ & $<1 \mathrm{~m}$ & $0.45-0.8 \mathrm{~m}$ \\
Permafrost temperature & $\sim 0^{\circ} \mathrm{C}$ & -2 to $-3^{\circ} \mathrm{C}$ & $-8^{\circ} \mathrm{C}$ & $-10^{\circ} \mathrm{C}$ & -6.5 to $-7^{\circ} \mathrm{C}$ \\
Soil type (mineral/organic) & Organic & Mineral & Organic & Organic & Mineral \\
\hline
\end{tabular}

tall (up to $1 \mathrm{~m}$ ) and can lead to a lower albedo in the models than reality, and thus faster snowmelt (this is modelled by interpolating between snow-covered and snow-free albedo depending on snow depth and vegetation height). At Bayelva, where the vegetation is particularly small $(\sim 5 \mathrm{~cm})$, there is a notable underestimation of the snow depth and early snowmelt in all models, which supports this hypothesis (snow at Bayelva can be modelled very well when vegetation is not included; López-Moreno et al., 2016). Snowdrift is only represented by scaling the snowfall data to match the observed snow accumulation, which limits the extent to which snowpack dynamics can be recreated by the models.

It is important to be careful when modelling snow depth based on single-point observations, as they may not be representative of the area as a whole. Further details on the representativity of snow depths are given in the Supplement. The sensitivity of carbon cycle processes to increased or reduced snowfall is discussed in Sect. 3.5 and 3.6.1.

\subsection{Soil temperature}

Soil temperature annual cycles at $\sim 40 \mathrm{~cm}$ depth are shown in Fig. 2. In general the models simulate the soil temperature at mineral soil sites quite well: see the Bayelva and Zackenberg sites in Fig. 2. There are greater errors in the simulation of organic soils: Abisko, Kytalyk and Samoylov in Fig. 2.

For JSBACH and ORCHIDEE, the annual cycles of temperature are too large for the organic sites, indicating that these models need to better represent the insulating and damping properties of organic soils. To illustrate this, additional observations from mineral soil at the nearby research station (where there is no permafrost) are shown on the Abisko plot (Fig. 2). This line matches much more closely with the ORCHIDEE and JSBACH simulations, suggesting that these models are behaving thermally like a mineral soil. At Abisko, permafrost only occurs in peat plateaus, and thus including organic soil properties in the models is essential for capturing the difference between permafrost and nonpermafrost conditions.

In JULES, however, the annual cycle amplitude is too small at the organic sites and also at Zackenberg, mostly due to biases in the winter soil temperatures. This suggests that the snow thermal conductivity or density may be too low in JULES. A similar problem was found with a previous JULES simulation of Samoylov island, using a similar model set-up and forcing data (Chadburn et al., 2015a). There, the winter soil temperature was improved by increasing snow density. Indeed, the conductivity of snow in the JULES simulations 
Table 3. Mean NEE budget $\left(\mathrm{g} \mathrm{C} \mathrm{m}^{-2} \mathrm{yr}^{-1}\right)$, showing that in general this is smaller than the errors in simulated GPP; therefore, the noise is larger than the signal in this data. Positive numbers represent a carbon source.

\begin{tabular}{lrrrr}
\hline Site & JSBACH & JULES & ORCHIDEE & Observations \\
\hline Abisko & -6.6 & -16.0 & -79.2 & -162.0 \\
Bayelva & -8.8 & -15.1 & -34.7 & -13.9 \\
Kytalyk & -19.0 & -18.9 & -24.3 & -108.0 \\
Samoylov & +1.5 & -15.1 & -58.9 & -49.6 \\
Zackenberg & +35.9 & -5.2 & +0.01 & -12.0 \\
Mean absolute error in GPP & 100.2 & 123.6 & 88.4 & - \\
\hline
\end{tabular}

(a)

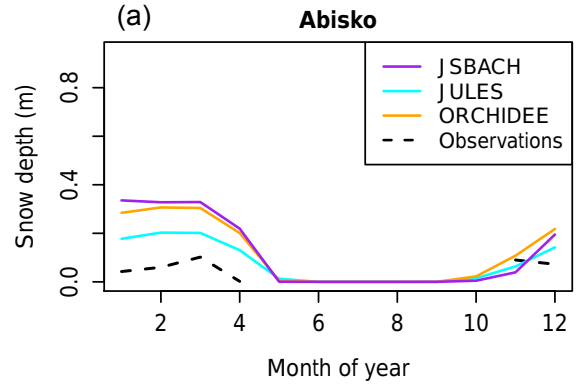

(c)

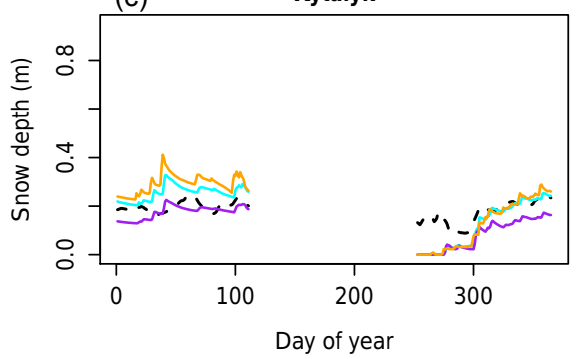

(e)

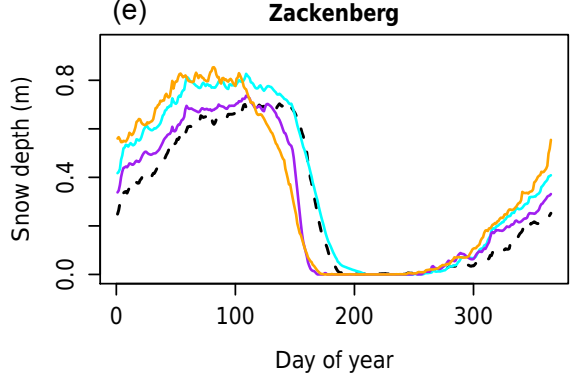

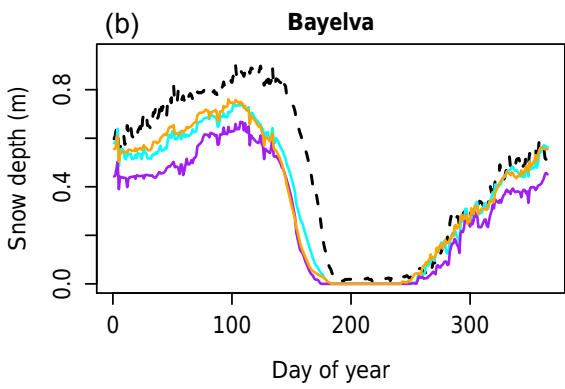
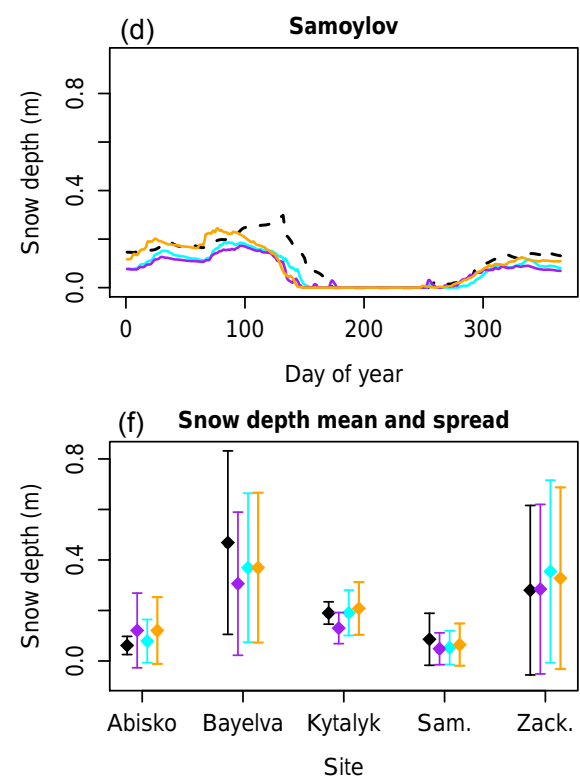

Figure 1. Mean annual cycle of snow depth at each site, showing both observations and models. In panel (f), Samoylov and Zackenberg are abbreviated to "Sam." and "Zack.". Mean annual cycle is calculated from a single site over a number of years, except for Abisko, where measurements were taken at several different locations in the mire. See Table S1 for the years used at each site.

is between 0.03 and $0.1 \mathrm{Wm}^{-1} \mathrm{~K}^{-1}$ at the sites with shallow snow (and in the upper layers of the snowpack at sites with deeper snow), which is considerably lower than typical values for similar tundra sites, which are around $0.2-$ $0.3 \mathrm{Wm}^{-1} \mathrm{~K}^{-1}$, at least for the upper part of the snowpack (Gouttevin et al., 2012b; Domine et al., 2016). See the Supplement for further discussion on snow conductivity and density.

\subsection{Soil moisture}

As with temperature, the (unfrozen) soil moisture is simulated well at mineral soil sites - see Bayelva and Zackenberg in Fig. 3. In the winter, ORCHIDEE does not represent the unfrozen water fraction in frozen soils, but the other models simulate a reasonable water content in winter. However, soil moisture is in general too low at organic sites - Samoylov and Abisko mire. The soils should be able to hold water near 

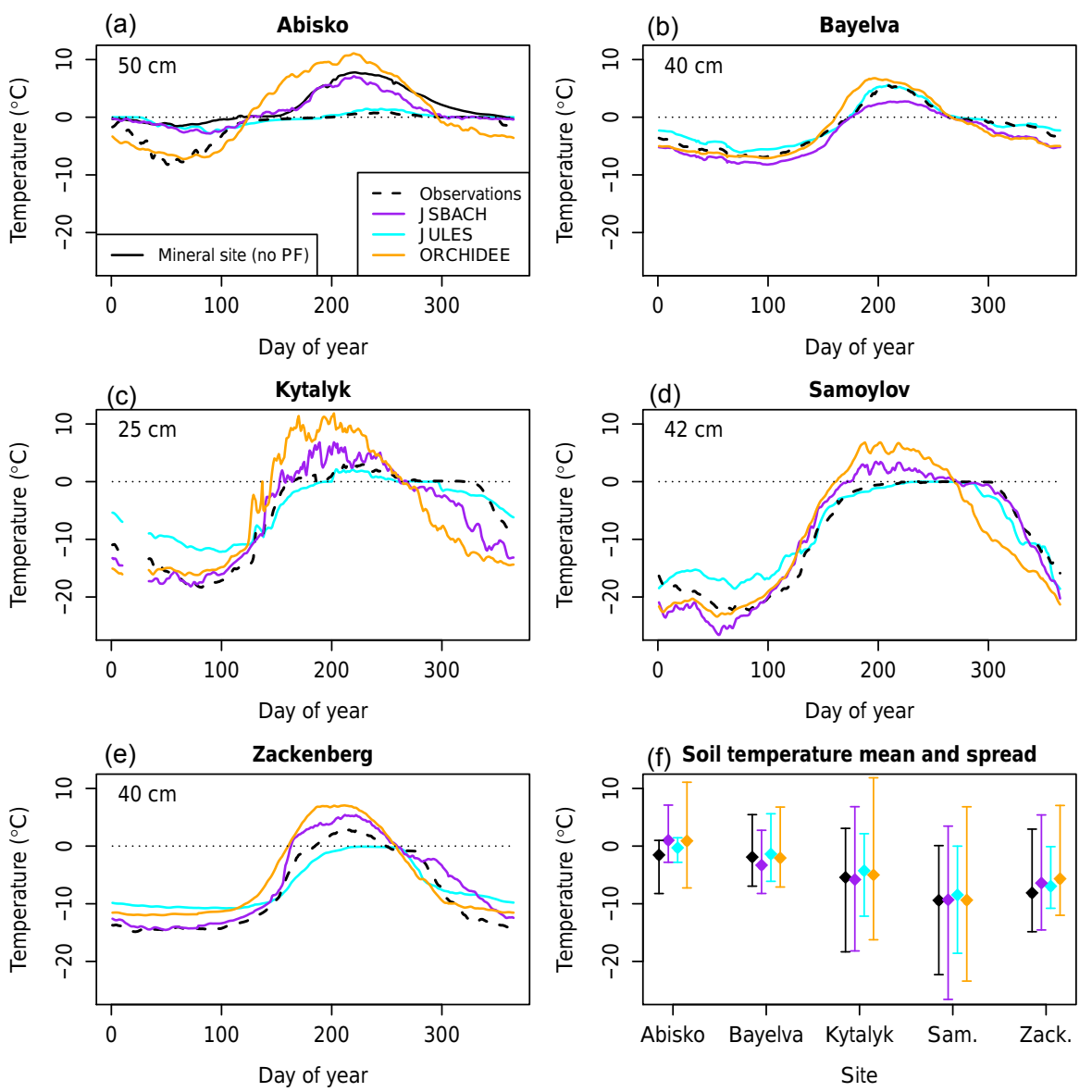

Figure 2. Mean annual cycle of soil temperature at each site, showing both observations and models. Depths of observations: Abisko: 50 cm; Bayelva: $40 \mathrm{~cm}$; Kytalyk: $25 \mathrm{~cm}$; Samoylov: $42 \mathrm{~cm}$; Zackenberg: $40 \mathrm{~cm}$. JULES and ORCHIDEE take the nearest soil layer and JSBACH is interpolated to the correct depth, as soil layers are not resolved well enough to get close to the right depth. In panel (f), Samoylov and Zackenberg are abbreviated to "Sam." and "Zack.". See Table S1 for the years used at each site.

the surface and remain saturated very close to the surface (or even above). This points to problems with the hydrology schemes. The soil moisture is very important for the soil temperatures, and it can also have a strong influence on soil carbon stocks and the partitioning of decomposition into $\mathrm{CO}_{2}$ and methane. Furthermore, it influences vegetation growth, and thus the uptake of $\mathrm{CO}_{2}$ from the atmosphere. Therefore, it is important to further improve the soil hydrology in these models.

Note that saturated zones can be influenced by landscape heterogeneity and lateral water fluxes that would not be captured in a point simulation. This can potentially be simulated by the models as a landscape average (see, for example, Gedney and Cox, 2003). However, such schemes simulate only a grid-box-mean water content, which does not capture, for example, the influence of anaerobic conditions on decomposition.

Figure 3 shows quite a large variation in the timing of freeze-up and thaw between the models, reflecting the soil temperature differences in Fig. 2. Correspondingly, the largest differences are at the organic soil sites.

\subsection{ALT}

The active-layer depth is shown in Fig. 4. In the models it is calculated with interpolation of soil temperatures to find the daily thaw depth, except in JULES, which uses the method of (Chadburn et al., 2015a). The two methods differ at most within the thickness of the soil layers; see Table A2. In ORCHIDEE and JSBACH the active layer is too deep, which corresponds to the too-warm soil temperatures in summer (Fig. 2). In JSBACH the summer temperatures are only a little warmer than the observations - certainly closer than in ORCHIDEE, yet at some sites the active layer is just as deep. This is because technically the ALT (active layer thickness) cannot be diagnosed correctly in JSBACH, given the thick soil layers below $20 \mathrm{~cm}$ depth (see Table A2). Increasing the resolution of the soil layers, while it does not make a big difference to the soil temperature profile, has a very large im- 

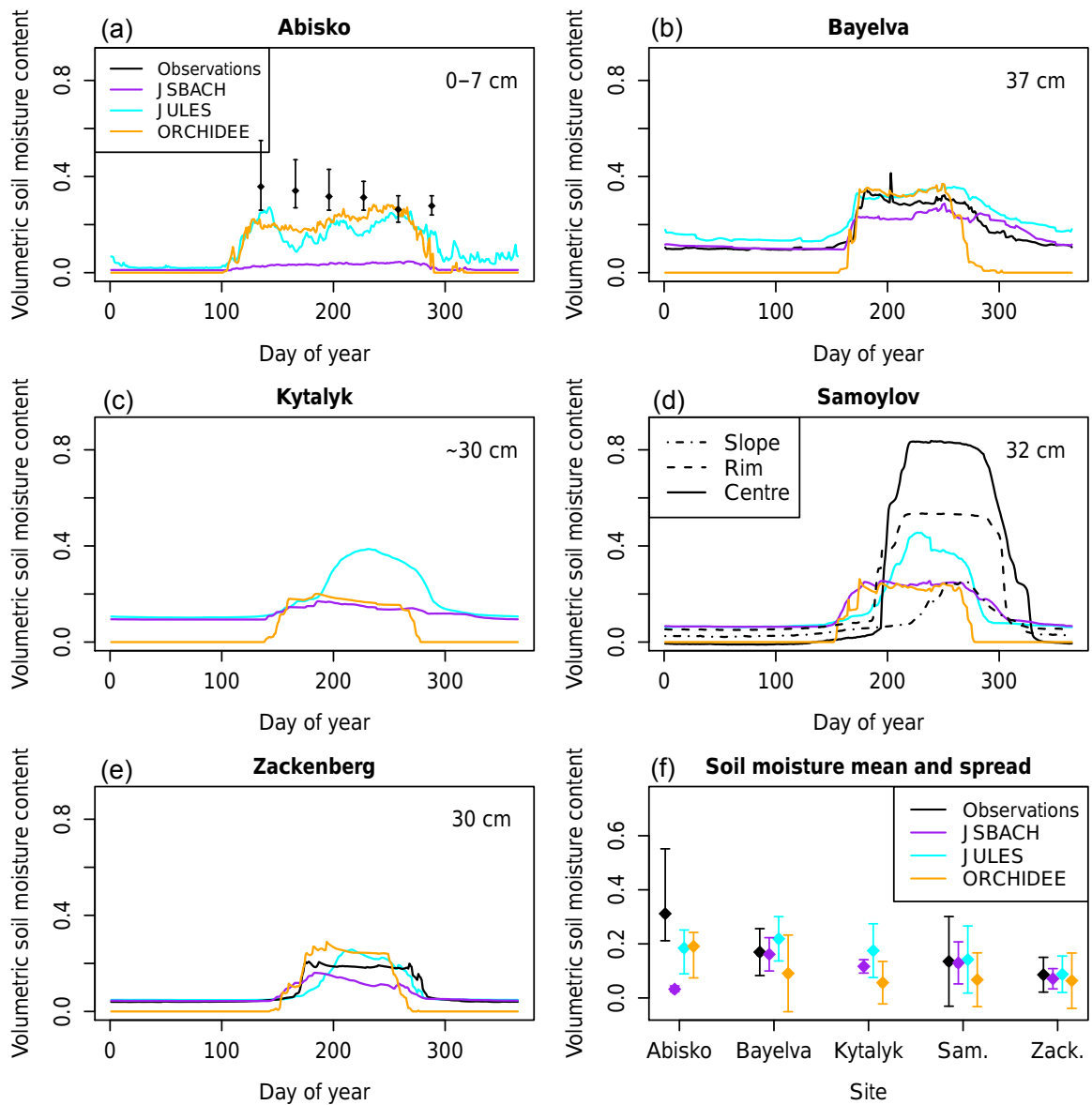

Figure 3. Mean annual cycle of unfrozen soil moisture at each site, showing both observations (where available) and models. Depths are as follows: JSBACH: $19 \mathrm{~cm}$ for all sites (this is the closest to $30 \mathrm{~cm}$ - the next layer is at $78 \mathrm{~cm}$ ), except Abisko, which is $3 \mathrm{~cm}$. JULES: $32 \mathrm{~cm}$ (except Abisko, which is $3 \mathrm{~cm}$ ). ORCHIDEE: $36 \mathrm{~cm}$ (except Abisko, which is $4 \mathrm{~cm}$ ). Observations: Bayelva: $37 \mathrm{~cm}$; Samoylov: $32 \mathrm{~cm}$; Zackenberg: $30 \mathrm{~cm}$; Abisko: 0-7 cm. For Samoylov, three different soil moisture profiles are shown that represent different parts of the polygonal microtopography. In panel (f), Samoylov and Zackenberg are abbreviated to "Sam.” and “Zack.". See Supplement Table S1 for the years used at each site.

pact on the simulation of the active-layer depth, as shown by (Chadburn et al., 2015b). In JULES there is generally quite a good match to the observations as supported by the fact that the summer soil temperatures match closely with the observations for most sites. For Zackenberg the active layer is a little too shallow, but still in the range of observed values. This shows the importance of both resolving the soil column and the insulating effects of organic matter for determining the summer soil temperatures (Dyrness, 1982).

\subsection{Soil carbon stocks}

JULES and ORCHIDEE represent a vertical profile of soil carbon, whereas JSBACH does not. Without a vertical representation of soil carbon it is not possible to simulate permafrost carbon stocks because all of the carbon is subject to the seasonal freezing and thawing of the active layer and the model does not contain any inert, permanently frozen carbon.
Therefore, a vertical representation of soil carbon is prerequisite for simulating soil carbon stocks at these sites. However, JULES and ORCHIDEE have some problems in simulating the profiles - Fig. 5. The most obvious problem is underestimation: there is much too little carbon simulated at many of the sites (see the last panel in Fig. 5, showing total column soil carbon). For the sites at which the quantity of soil carbon is somewhat realistic, the shape of the profiles vary from a steep exponential-looking decay with depth to a shallower decline with more carbon in the deeper soil. The same kind of profiles are seen in the observations, particularly for the mineral soil sites (Bayelva and Zackenberg). However, neither of the models can produce the carbon-rich peaty layers of the organic soils. To simulate this would require additional process representation in the models, including representing saturated (and thus anaerobic) conditions in peat soil, and a dynamic representation of bulk density. 

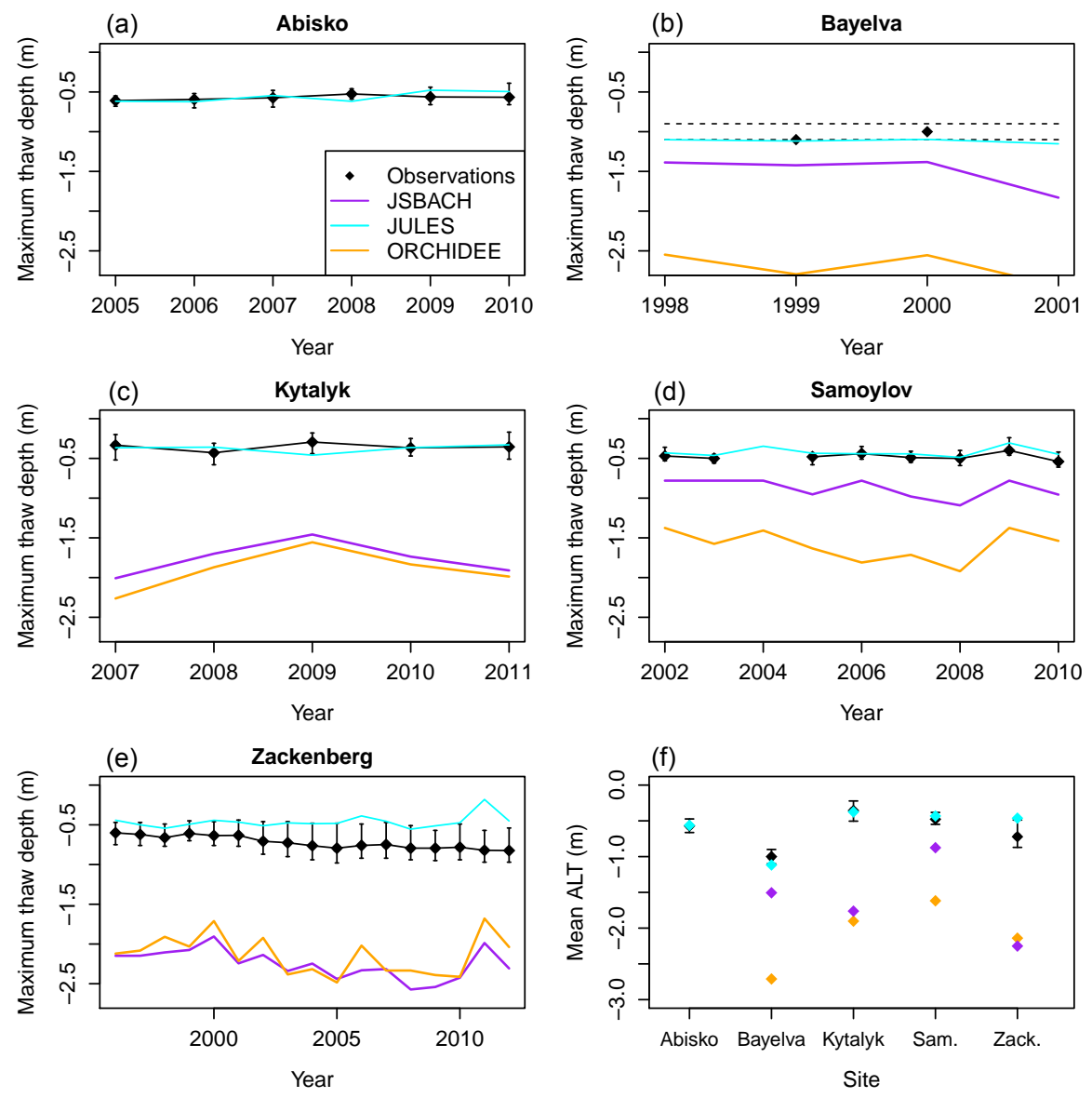

Figure 4. Maximum summer thaw depth (active layer) over a number of years at each site, comparing observations and models. Dotted lines in panel (b) represent the range of observed estimates. For all other panels, CALM grids are used, and the error bars show the full range of measured values in the grid. In panel (f) the error bars show the mean of the upper and lower limits from the previous panels.

The reasons for the major underestimation are different in JULES and ORCHIDEE. In JULES, the main problem is that the GPP is underestimated; therefore, there are not enough plant inputs to accumulate carbon in the soil. This is made clearer by Fig. 6, which shows the relationship between GPP and the top $1 \mathrm{~m}$ soil carbon stocks. In JULES, the relationships are very similar to the observations, which indicates that the turnover of carbon in the soil is reasonable in JULES. Therefore, if the GPP were large enough, the soil carbon stocks would be much more realistic. In ORCHIDEE, the story is different. Even when the vegetation is productive, the soil carbon stocks are still very low. This indicates a problem with the soil carbon decomposition. There are two factors that could affect this. Firstly, the soil temperatures in ORCHIDEE are much too warm, and the active layer is too deep (Figs. 2 and 4). This can lead to too much decomposition. In order to improve this, the model needs to better represent the insulation from the organic soils. Another possible problem is the deep soil respiration. In ORCHIDEE the only factor that suppresses the soil respiration at depth is the cold and/or frozen nature of the ground. In JULES, however, there is an additional decay of respiration with depth that empirically represents some processes that are missing in the model (following the implementation in the Community Land Model; see Koven et al., 2013). Including this in ORCHIDEE could lead to a higher carbon stock at depth. The deeper soil carbon stocks are also influenced by long-term burial processes, which are only represented by a simple diffusion scheme in these models. We include JSBACH in Fig. 6 because the top $1 \mathrm{~m}$ of soil carbon is mostly in the active layer. Given that the decomposition in JSBACH is controlled by the temperature of the top soil layer $(3 \mathrm{~cm})$, it is not surprising that the relationships are not captured perfectly, as the upper soil layer will be much more sensitive to variations in temperature than the deeper ones. However, on average the turnover is quite realistic for this model.

It should be noted that the observed relationship in Fig. 6 may be confounded by the history of soil carbon formation at these sites. There is inconsistency between Holocene climate and the pre-industrial climate used in model spin-ups. Re- 

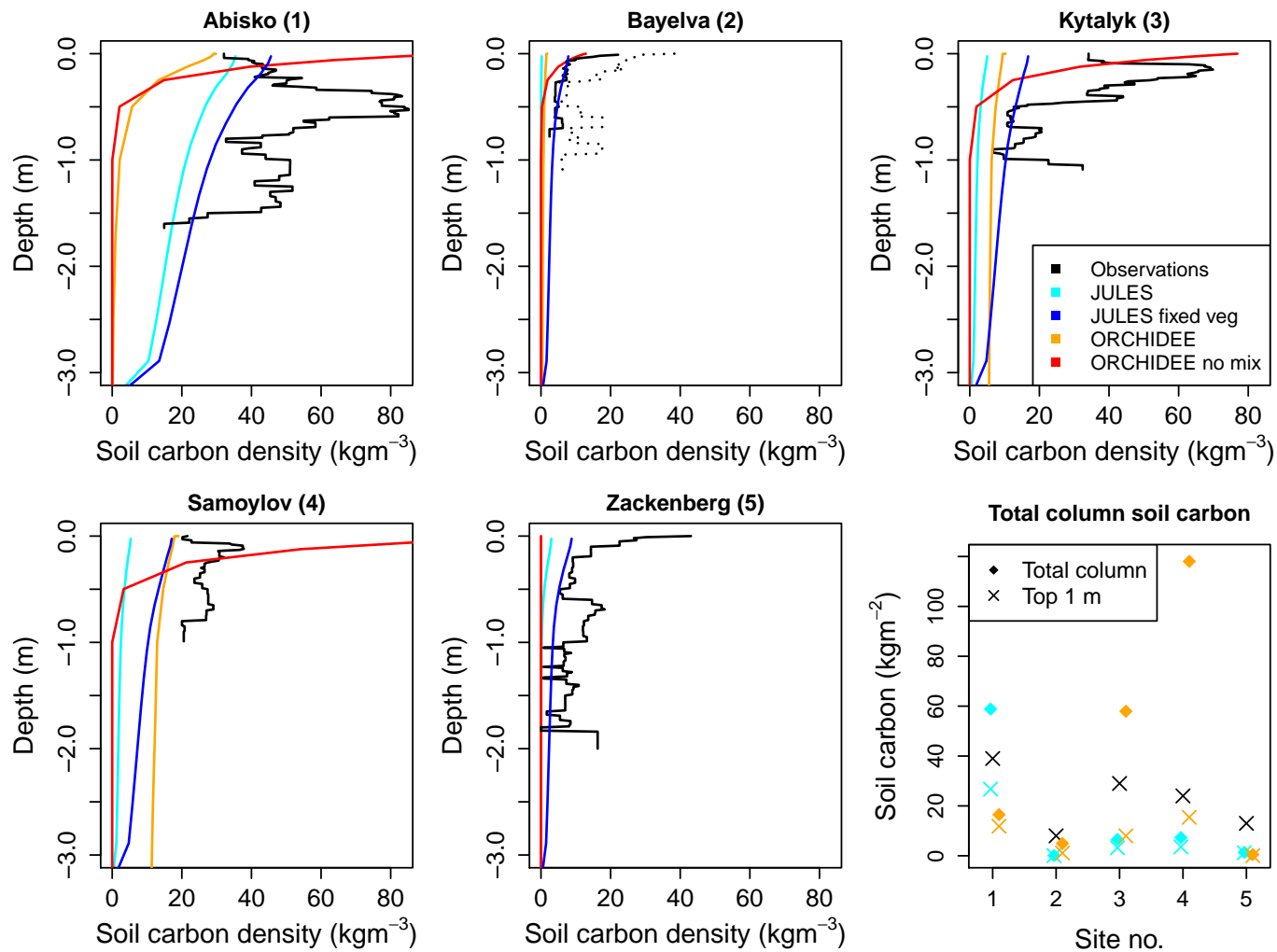

Figure 5. Profile of soil carbon at each site $\left(\mathrm{kg} \mathrm{m}^{-3}\right)$. Observations and two of the models (ORCHIDEE and JULES) are shown, as these models have a vertically resolved soil carbon profile. Dotted and solid lines in the second panel (Bayelva) show two different land cover types in the vicinity of the site (solid: barren ground; dotted: sparse shrub-moss tundra.) Note that site numbers in the last panel are given in the headings of the preceding panels.

constructed Holocene climate for the Northern Hemisphere is warmer than pre-industrial (Marcott et al., 2013), and possibly wetter, favouring the formation of peat; thus, some underestimation by the models may be expected.

The soil carbon stocks are sensitive to changes in snow depth in these models (see Fig. S8), through changes in soil temperature (JSBACH) and changes in vegetation growth (JULES). In JULES, both vegetation and soil temperature changes affect the soil carbon, but the vegetation effect dominates. In fact, for two of the sites (Kytalyk and Samoylov), the vegetation coverage is so different during spin-up that the simulation with increased snowfall accumulates twice as much soil carbon as the default case (although the stocks are still much too small and the absolute difference is less than $10 \mathrm{~kg} \mathrm{~m}^{-2}$ in the whole soil column).

We conclude that improving soil carbon stocks demands a different priority in each model. For JULES, the first priority is to simulate realistic vegetation productivity, for ORCHIDEE it is to improve the soil carbon decomposition and for JSBACH it is to represent a vertical profile of soil carbon. Assuming we can combine the best features from all of the models, the greatest difference between the observed and simulated profiles will be the peaty, organic layers that are present in observations and not models (Fig. 5). Therefore, the next priority for model development is to better represent these organic soils. See Frolking et al. (2010) and Schuldt et al. (2013) for examples of modelling peat. While peatlands represent a small fraction of the land surface, they contain very large carbon stocks (Yu et al., 2010); thus, it is important to include them in ESMs.

\subsection{Carbon fluxes}

Figure 7 shows the seasonal cycle of $\mathrm{CO}_{2}$ flux at every site. The daytime and night-time fluxes are plotted separately (partitioned by incoming shortwave radiation), showing in general uptake during the day and emissions during the night. For the most part, the models show uptake and emissions at the same time as the observations and a similar timing of peak uptake and emission (one exception being the spring daytime flux in ORCHIDEE; see Sect. 3.6.1).

From the observations we also have the gap-filled estimates of annual GPP and Reco, which are compared with the annual totals for each model in Fig. 8 (the moss GPP shown here is discussed in Sect. 3.6.3). For the GPP we see that for each model there is a positive correlation (sites with 


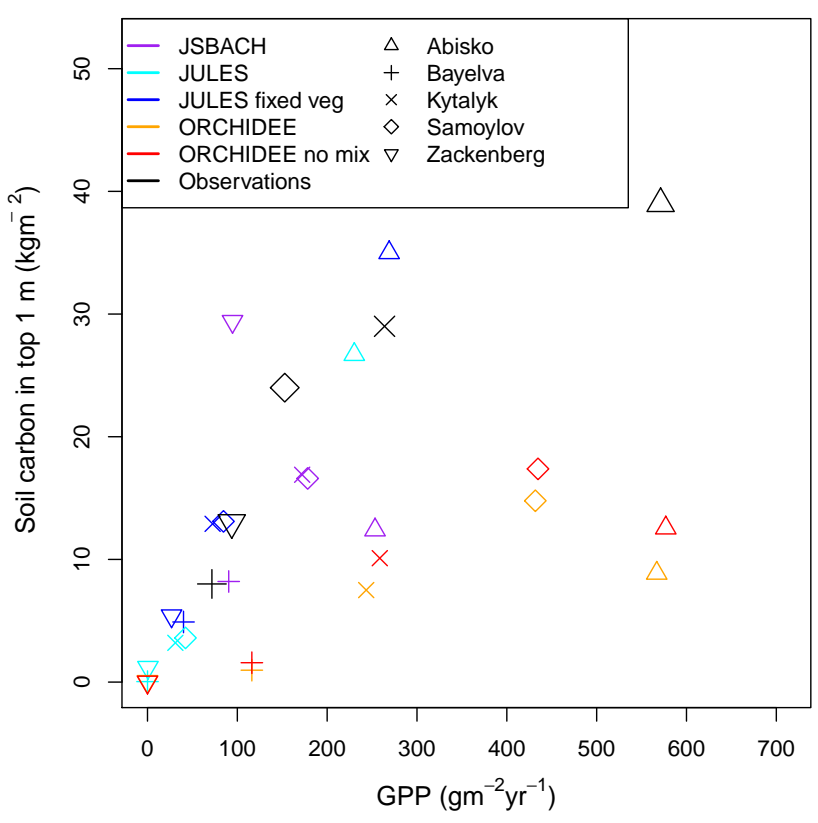

Figure 6. GPP compared with the top $1 \mathrm{~m}$ soil carbon at each site. The top $1 \mathrm{~m}$ soil carbon values are for the tower footprint area (see Table S2), so that equivalent values are being compared.

larger GPP in reality have larger GPP in the models), but that the overall values are too small for JULES, for ORCHIDEE there is a bigger variation, and for JSBACH they tend to be too large for the less productive sites and too small for the more productive sites - i.e. the slope of the relationship between model and observations is too shallow. Nonetheless, a significant amount of the variation between sites is captured by the models, to which the only inputs are climate data and soil properties. Of these, climate is the main driver of vegetation growth in these models (since nutrient limitation is not included, the soil only impacts the vegetation through moisture stress - which is also partly climate-related). Therefore, we can say that a lot of the difference between the GPP and Reco across different sites is due to the difference in climate. In fact, in JULES and JSBACH, over $90 \%$ of the variation in GPP between sites is explained by the model, despite the systematic biases ( $\mathrm{R}$ squared values of modelled GPP against observed GPP: JSBACH - 0.94; JULES - 0.95; ORCHIDEE - 0.63). This suggests that a model based on climate alone and with one tundra PFT could capture most of the variability in tundra carbon uptake, if the vegetation was correctly calibrated. This is a promising sign that the model simulations could be easily improved.

Due to the magnitude of errors in GPP and Reco, when considering the difference between the two - the NEE - the noise will be larger than the signal. Nonetheless, the models and observations both generally show a carbon sink in the present day due to environmental conditions being more favourable for growth (warmer, more $\mathrm{CO}_{2}$ ) than in the preindustrial spin-up period (Table 3).

\subsubsection{Drivers of carbon fluxes}

The models indicate different drivers of GPP in different parts of the growing season. In particular, the increase in GPP in the first half of the season is driven by increasing LAI, and the downward trend in GPP in the second half of the season is driven by shortwave radiation. There is also a temperature dependence in all parts of the growing season. These relationships are shown in Fig. S1. Figure S1 also shows the plant respiration in the models, which exhibits a similar behaviour to the GPP, being influenced by temperature, shortwave radiation and LAI. The fact that these variables influence the GPP and autotrophic respiration is clear from the model structure (for example Knorr, 2000; Clark et al., 2011); however, the apparent split between the two halves of the season is an emergent behaviour.

The other component of the Reco is heterotrophic respiration. This does not exhibit the same dependencies as the plant respiration as it is determined by below-ground conditions. The heterotrophic respiration has a loose relationship with air temperature and a much stronger relationship with the $\sim 20 \mathrm{~cm}$ soil temperature - see Supplement Fig. S2.

In order to compare the photosynthesis schemes in the models more directly, we normalise by the LAI. It then becomes clear that the photosynthesis models in JSBACH and ORCHIDEE are in fact quite similar. Figure 9 shows the normalised GPP (per square metre of leaf) plotted against the air temperature and shortwave radiation. JSBACH and ORCHIDEE show similar relationships, although ORCHIDEE still has a slightly higher GPP, potentially explained by the fact that the $V_{\mathrm{c}, \max }$ is higher. In these plots we also show the limited data that we can plot from observations using MODIS LAI. It is clear that the normalised GPP in JULES is too low (this is a problem, probably related to canopy scaling, that requires attention in the model), but for JSBACH and ORCHIDEE the GPP is approximately consistent with the observations. The observations are a little higher than the models, but this is largely influenced by underestimated LAI at Samoylov (note that for the other sites, MODIS LAI compares reasonably with ground-based estimates). Moss cover is close to $100 \%$ at Samoylov (Kutzbach et al., 2007) and, by contrast, maximum LAI from MODIS is only around 0.3 . This could be due to the large size of the MODIS pixels $(1 \mathrm{~km} \times 1 \mathrm{~km})$ leading to the inclusion of water in the pixel, or because the moss has a different absorption spectrum from vascular plants and could register as bare soil. Whatever the cause, the GPP per unit LAI at Samoylov would be at least doubled by this underestimation of LAI, and if we were to account for this, the observation-based estimates would be very close to the JSBACH and ORCHIDEE results.

Aside from JULES being biased low, we therefore conclude that the main source of error in the modelled seasonal 

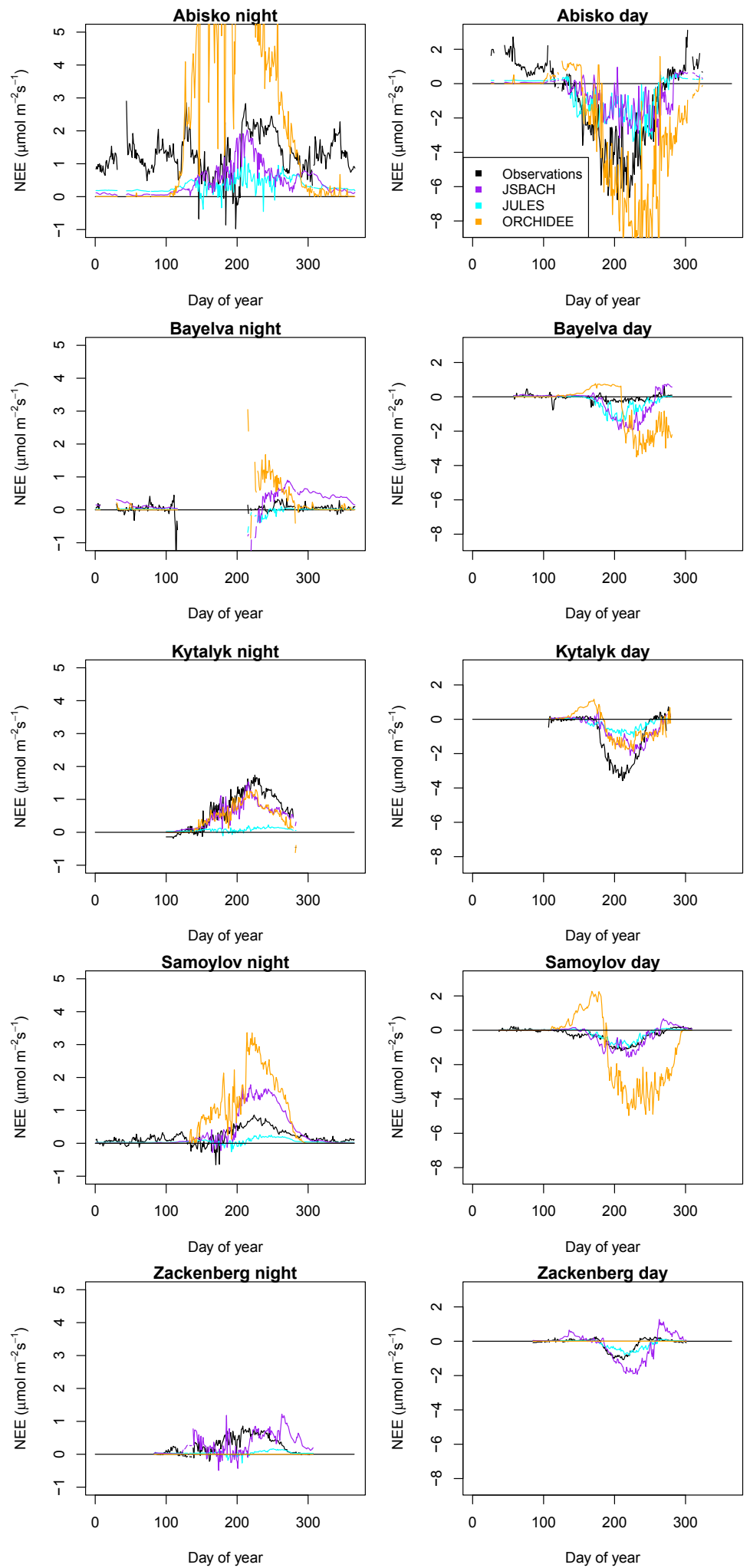

Figure 7. Mean annual cycles of $\mathrm{CO}_{2}$ fluxes for all sites, observations and models. Left: night-time flux; right: daytime flux (corresponding to incoming shortwave radiation $>20 \mathrm{Wm}^{-2}$ ). See Table $\mathrm{S} 1$ for the years used at each site. 

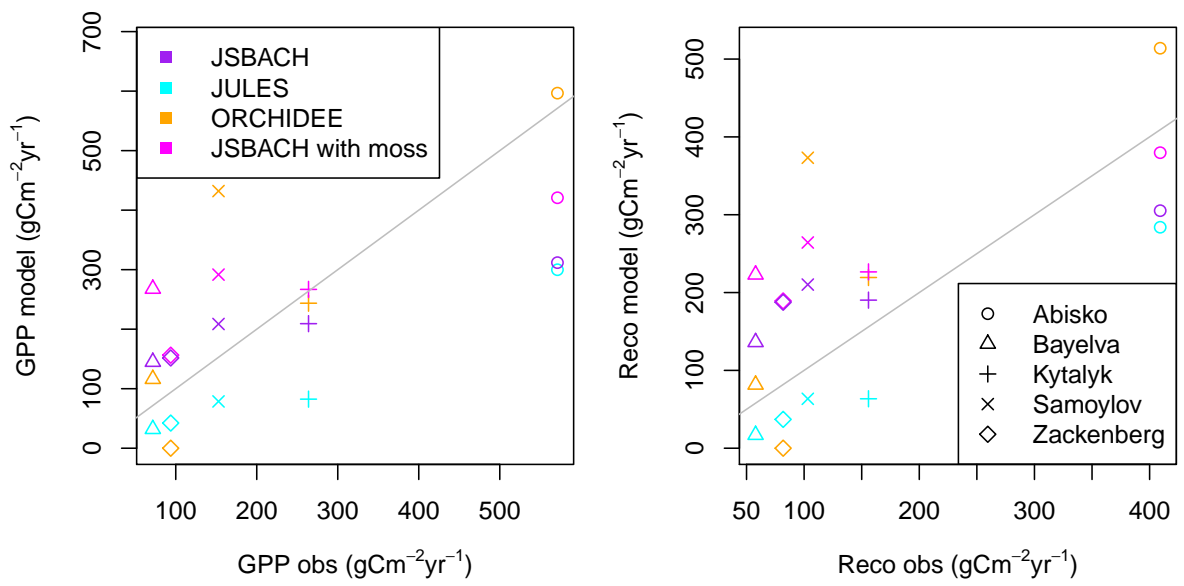

Figure 8. Mean annual GPP (gross primary productivity) and Reco (ecosystem respiration) from the models, plotted against the observationderived values for the same time periods. See Table S1 for the years used at each site.
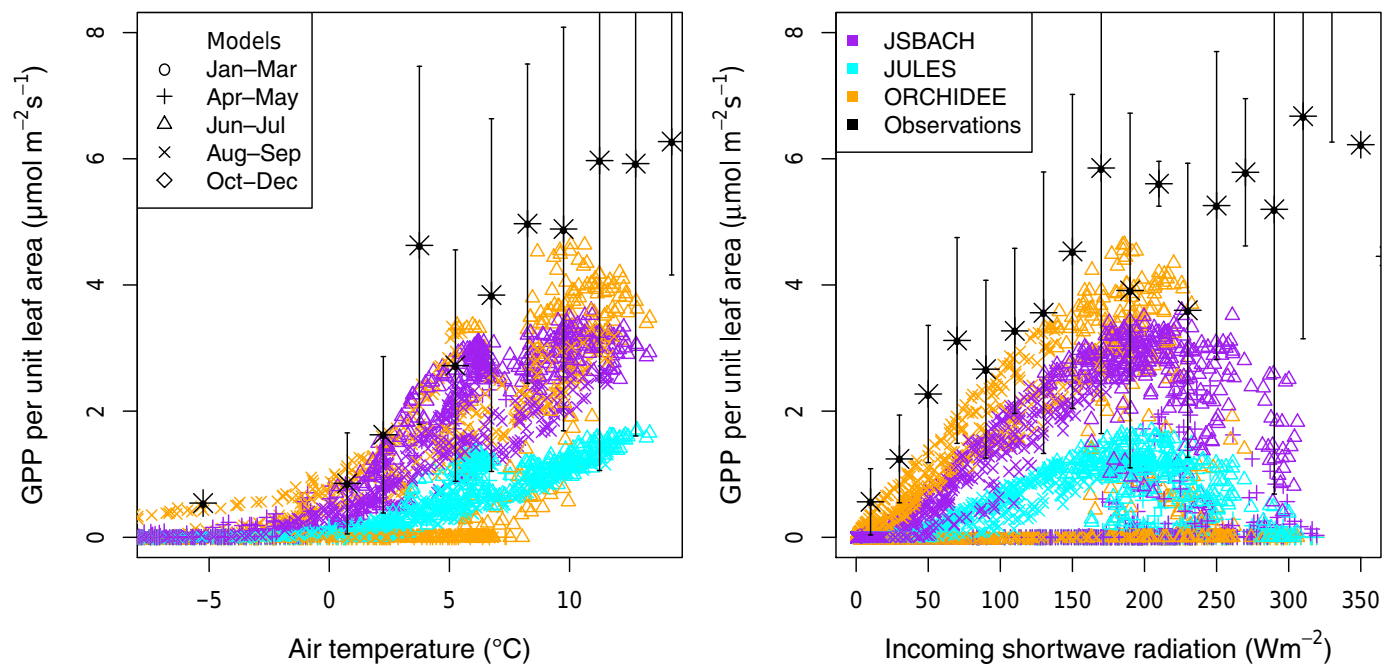

Figure 9. Relationship of normalised GPP (GPP per square metre of leaf) to air temperature and incoming solar radiation. All models and sites are shown, plus observationally derived values using GPP estimated from eddy covariance data and LAI from MODIS (MODIS15A2, 2016); see Sect. 2.1.8.

cycle of GPP is the huge variation in the simulated LAI. This is shown in Fig. 10. For example, ORCHIDEE LAI remains at zero in the early season, when the observations and other models show carbon uptake, and it suddenly increases to a very large value later in the season, then showing an uptake that is much larger than the observations (Fig. 7). In fact, at Zackenberg the cumulative temperature is never high enough to initiate budburst in the model; thus, the LAI is always zero. These problems lead to unrealistic daytime emissions during spring from ORCHIDEE in Fig. 7 for most sites, and no fluxes at all for Zackenberg. Since the GPP seems to be consistent with observations when the impact of LAI is removed, we conclude that if the models could simulate the correct LAI they would largely simulate the correct GPP. JULES captures more of the difference in LAI between the sites than the other models (and subsequently captures more of the intersite variation in GPP). This is because JULES is running a dynamic vegetation scheme that allows the vegetation fraction to vary. The LAI from JULES with fixed vegetation is also shown in Fig. 10 and captures less of the inter-site variability. Therefore, both improving the LAI and including a dynamic vegetation scheme is the priority for improved simulations of tundra carbon uptake.

Carbon fluxes are also sensitive to soil moisture, as seen in simulations with increased or decreased snowfall, in which differences in soil moisture availability in summer are reflected by changes in annual mean GPP, Reco and vegetation fraction in JULES (Fig. S7), in line with (Frost and Epstein, 2014). Therefore, realistic simulation of precipitation 

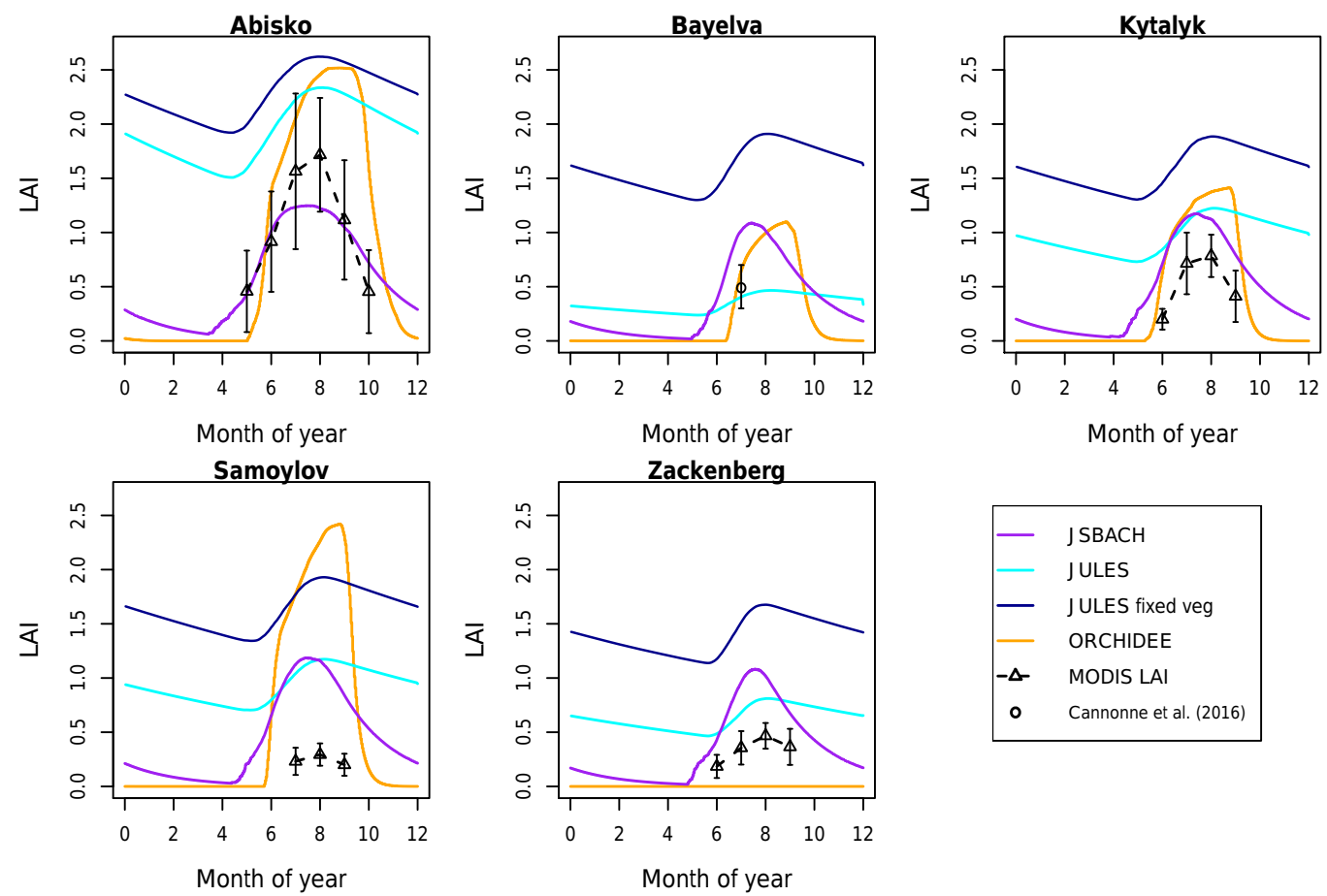

Figure 10. Mean annual cycles of LAI (leaf area index) for each site. Observed values are from the MODIS LAI product (MODIS15A2, 2016), except Bayelva, which is from (Cannone et al., 2016).

and soil moisture is a pre-requisite for improved LAI and vegetation dynamics.

\subsubsection{Components of respiration}

If the system were in equilibrium, the annual mean Reco would be equal to the GPP. Thus, improving the simulation of GPP would by default improve the simulated respiration. However, the seasonal cycle of respiration is significantly different from that of GPP due to the heterotrophic component. This is particularly true in cold climates as the soil temperature can lag a long way behind air temperature due to the latent heat of freezing-thawing. Furthermore, the response of respiration to changing conditions must be correctly simulated; otherwise any shift from the equilibrium state - a net source or sink of carbon - will not be correctly simulated.

It is difficult to compare the modelled respiration fluxes with the eddy covariance data (other than the annual mean). This is because the gases are assumed to be immediately emitted from the soil in the models, whereas in reality they can accumulate in the soil profile and diffuse upwards with a significant delay. The accumulated gas may also be released from the soil in bursts, e.g. in the case of Bayelva, where the bursts of emissions in the autumn season correspond to heavy rainfall events, which (it is hypothesised) may be forcing the gas out of the soil (J. Boike, personal communication, 2016). Similarly, strong autumn emissions of $\mathrm{CO}_{2}$ from the soil were observed with chamber measurements at Zacken- berg due to the freezing of the active layer forcing out bubbles of gas (Mastepanov et al., 2013). Further difficulty is introduced since the heterotrophic and autotrophic components cannot be separated in the measurements. Therefore, we cannot evaluate the soil respiration schemes in detail without direct measurements in the soil. However, one conclusion we can make is that for some models the soil carbon is approximately correct when the inputs to the system (GPP) are correct (Fig. 6), which gives some indication that the decomposition models behave reasonably in these conditions.

\subsubsection{Nutrient limitation and moss}

We have discussed the need for a dynamic vegetation model to capture the inter-site differences in LAI, as shown in Fig. 10, in which JULES, using a dynamic vegetation model, captures much more of the inter-site variability than the other models. However, looking more closely highlights some missing processes.

For example, the LAI at Bayelva is very small (close to zero) during the early part of the JULES simulation, but between around 2002 and 2006 it rapidly increases to around 1. To illustrate this transition, the fractional coverage of vegetation in JULES is shown in Fig. S3. In reality, vegetation cannot establish rapidly at a site such as this (even if climatic conditions become appropriate) because of the lack of a soil matrix and nutrients needed for plant growth, particularly nitrogen. Vascular plants could take hundreds of years to es- 
tablish once climatic conditions become appropriate due to the large timescales involved in soil development. The vegetation at Bayelva is largely mosses and lichens, which can grow in nutrient-poor conditions but photosynthesise more slowly than vascular plants (Yuan et al., 2014). Therefore, to simulate the $\mathrm{CO}_{2}$ flux at a very nutrient-limited site, it is necessary to have a different PFT that represents the low-nutrient but low-GPP vegetation such as moss and to include nutrient limitation for the other PFTs.

A similar problem can be seen at Samoylov, where around $90 \%$ of the site is covered by moss (Boike et al., 2013), and JULES simulates an LAI similar to that of Kytalyk (as the climatic conditions are similar), but in reality the LAIs of the two sites are very different; at Samoylov the LAI (of vascular plants) and $\mathrm{CO}_{2}$ flux should be much smaller than that of Kytalyk. At Samoylov, the moss contributes around $40 \%$ to the total photosynthesis (Kutzbach et al., 2007), showing its importance in the carbon budget of this site. It is hypothesised that there are fewer vascular plants at Samoylov because the more waterlogged conditions (due to many polygon centre ponds) could reduce vegetation growth. In fact, reduced vegetation growth is also seen in areas with many polygon centre ponds at Kytalyk. Moreover, nitrogen may be lost in these waterlogged environments due to denitrification (Palmer et al., 2012), making it a more nutrient-limited environment.

Thus, to really capture the inter-site differences in GPP, it is necessary to include nutrient limitation and other soilplant interactions in the model. And once nutrient limitation is introduced, then moss is required (which grows in nutrientdeficient and very wet conditions in which the vascular plants will not grow) in order to recreate the observed carbon uptake.

In JSBACH, moss carbon fluxes can be included - see Fig. 8. This shows that the moss model can contribute significantly to the carbon budget at the mossy sites. However, at the sites with less vascular vegetation in reality (Bayelva and Samoylov), including the moss makes the total fluxes much too large, as JSBACH (like JULES) simulates too much vascular vegetation.

At Samoylov there is an early-season peak of carbon uptake that is missed in the models (Fig. 7). It is possible that this could correspond to the wet ground directly following snowmelt, which leads the moss to start photosynthesising. However, it is difficult to make conclusions from the data available, and we also know that eddy covariance methods can have some problems around the time of snowmelt (for example Pirk et al., 2017). Nonetheless, we can get a clue from the moss model in JSBACH. Figure S4 shows the annual cycle of moss GPP along with the GPP from JSBACH (without moss), demonstrating that it captures an early-season peak before the vascular plant uptake starts in JSBACH. This plot also shows the moisture content of the moss layer, making it clear that there is a strong relationship between moisture content and moss photosynthesis. Thus, it becomes even more important to simulate soil moisture correctly once moss is included in the models.

It could also be important to consider lichens separately from mosses, as their physical and biological properties can be very different. For example, the high albedo of lichens can impact the Earth's radiation budget (Bernier et al., 2011).

\section{Conclusions}

Based on the analysis above, we can identify priority developments that would improve the carbon stocks and fluxes in the models. Assuming that "state-of-the-art" is represented by a combination of the best parts of each model, we provide the following priorities for the next steps to advance the state-of-the-art models:

1. Improve vegetation phenology and dynamics to simulate realistic LAI (including nutrient limitation and dynamic vegetation).

2. Include moss for both photosynthesis and peat accumulation.

3. Improve the soil carbon profile for organic soils (including peat processes).

There is also a need to address remaining issues in the model physics, particularly for soil moisture and snow. There are feedbacks between the vegetation and the soil physical state (e.g. Sturm et al., 2001); thus, incorporating more realistic vegetation such as Arctic shrubs could also lead to an improved simulation of soil temperature and moisture.

Tundra vegetation should ideally be represented using several different PFTs, for example grasses and shrubs differ in carbon storage and their interactions with snow. Note that JULES includes a shrub PFT, but these are large shrubs $(\sim 1.5 \mathrm{~m}$ tall), which would not be expected to grow at the cold sites. Smaller, cold-tolerant shrubs should be added as a separate PFT. There are few modelling studies to date in which tundra phenology is explicitly considered, but see Van Wijk et al. (2003) for one example.

In JSBACH the moss photosynthesis is already simulated, and the coupling to the soil carbon will be available in the next version. This provides clear guidance for other models to follow; see Porada et al. $(2013,2016)$. However, since JSBACH does not include nutrient limitation, the combined GPP and Reco from vascular vegetation and moss is too high (Fig. 8). Including nutrient limitation is an essential part of these priority developments.

In order to facilitate improvements to the vegetation schemes, better site-level measurements of LAI are required. This was identified as one of the largest modelling uncertainties, but only indirect satellite-derived LAI products are available, which are not sufficiently detailed or accurate for developing the model schemes. Furthermore, in order to improve the simulation of soil carbon profiles, better observa- 
tions and understanding of all below-ground processes such as in situ decomposition rates and the dynamics of cryoturbation mixing are required (Beer, 2016).

Future changes in NEE are key to understanding the role of the Arctic in a global context. We can see in Table 3 that the size of the NEE is much smaller than the errors we are currently seeing in, for example, the simulated GPP. This supports the need for the model improvements highlighted above.

Future changes in the carbon balance will come both from changes in vegetation productivity and type, and decomposition of old soil carbon due to thawing permafrost. Therefore, dynamic vegetation (including nutrient limitation) is required for future simulations as well as for simulating the correct LAI in the present day. The vertical representation of soil carbon is therefore also particularly important for the fluxes in the future. However, soil carbon release will also be triggered by landscape dynamics like ground collapse and thermokarst formation, which are not yet represented in any of these models. See (Schneider von Deimling et al., 2015) for a modelling study in which some of these impacts are included. This is another important aspect that must be taken into account in future model development (Rowland and Coon, 2015).

The feedbacks between the Arctic and the global climate are strongly dependent on whether carbon is released into the atmosphere from heterotrophic respiration as carbon dioxide or methane. The modelling capability at the time of this study was not sufficient to simulate the methane flux. However, this development is in progress (see, e.g. Kaiser et al., 2017), and represents an important topic for future work. Lakes and ponds also play a major role in methane and carbon dioxide exchange with the atmosphere (Bouchard et al., 2015; Langer et al., 2015) and should also be considered in future land surface models.

Accurate process representation at a site level will not necessarily transfer the same level of accuracy to a global simulation. In particular, there are issues with using a single gridbox-mean value to represent a large area of land (heterogeneity in soil and microtopography exerts non-linear controls on carbon and vegetation dynamics) and with obtaining realistic large-scale observations for quantities such as soil parameters. Conversely, the sites used in this study represent typical tundra sites, and the model development priorities that we identify are consistent across sites, indicating that these would also lead to improved tundra carbon dynamics in global simulations. This study has allowed us to quantify deficiencies in the models that we could not have robustly identified using global datasets due to the quantity and quality of observational data available. This work also opens up opportunities for further process studies in the future.

Data availability. The land surface model JSBACH used in this study is intellectual property of the Max Planck Society for the
Advancement of Science, Germany. The JSBACH source code is distributed under the Software License Agreement of the Max Planck Institute for Meteorology and it can be accessed on personal request. The steps to gain access are explained under the following link: http://www.mpimet.mpg.de/en/science/models/ license/. The model version JULES vn4.3_permafrost was used in this study. This version is described in Burke et al. (2017) and available via the Met Office Science Repository Service (on request for access) at https://code.metoffice.gov.uk/trac/jules/browser/main/ branches/dev/eleanorburke/vn4.3_permafrost. The ORCHIDEEMICT high latitude model version used in the study is described in Guimberteau et al. (2017). The SVN version of the code branch is https://forge.ipsl.jussieu.fr/orchidee/browser/ branches/ORCHIDEE-MICT. Please contact the corresponding author for the code of the ORCHIDEE-MICT if you plan an application of the model and envisage longer-term scientific collaboration. Carbon dioxide flux data and meteorological data for all sites are available from the European Fluxes Database Cluster http://www.europe-fluxdata.eu under site codes: SE-St1 (Abisko), NO-Blv (Bayelva), RU-Cok (Kytalyk), RU-Sam (Samoylov) and DK-ZaH (Zackenberg). Samoylov and Abisko are "closed" sites meaning that the site principal investigator (PI) must approve any download of the data. Site PI's should be invited to join any study using this data - see the website for detailed policies. CALM data for active layers can be accessed via the following database: https: //www2.gwu.edu/ calm/. Soil carbon profiles are being processed for inclusion into the next generation of the International Soil Carbon Network database (https://doi.org/10.17040/ISCN/1305039), and until then they are available upon request. Other data (including snow depth, soil temperature) for Samoylov and Bayelva sites are described in Boike et al. (2013) and Boike et al. (2017) (respectively) and available via permanent repositories detailed within. All other data from Kytalyk is available on request. All other data from Zackenberg is available via the Greenland Ecosystem Monitoring Programme (http://data.g-e-m.dk). Abisko meteorological data and snow depth data are available on request from the Abisko Scientific Research Station (https://polar.se/en/research-in-abisko), and the soil temperature data is archived in the GTN-P database (https://gtnp.arcticportal.org/). 


\section{Appendix A: Details of model set-up}

Mineral soil properties were calculated from sand-silt-clay fractions. Slightly different pedotransfer functions are used in each model, but they are all taken from the same baseline soil texture (see Table A1). For JULES, the organic soil fraction as a function of depth was estimated using the bulk density and carbon density. The combined organic and mineral soil properties were then calculated as in (Chadburn et al., 2015a).

The assumed "fresh" snow density for creating snowfall time series from snow depth depends on the resolution of the data. If we have low-resolution snow depth data, there may be some compaction between the snow landing and the measurement being taken; thus, we will use a higher density to generate the time series. The density used for most sites, hourly to daily resolution, is $180 \mathrm{~kg} \mathrm{~m}^{-3}$. At Abisko, only 5-daily snow depth data were available, and this was at the research station rather than the mire. Since this is a relatively warm site leading to more melting, and due to the long time interval between readings, in order to give enough snow in the models, a density of $240 \mathrm{~kg} \mathrm{~m}^{-3}$ was used. For the Abisko mire there were just a handful of snow depth measurements each year. All available values taken during a given month were averaged to give a monthly average time series of snow depth. We compared the depth with the model output from JULES using the forcing data prepared from the research station. The snowfall was then scaled according to the ratio of monthly snow depth in the model vs. the observations. This approach introduces uncertainties that would be reduced by the availability of a higher-resolution snow depth dataset from Stordalen mire. 
Table A1. Parameters for the sites. ${ }^{1}$ (Klaminder et al., 2008). ${ }^{2}$ J. Boike, personal communication, $2015 .{ }^{3}$ (Van Huissteden et al., 2005 ). 4 (van der Molen et al., 2007). ${ }^{5}$ (Boike et al., 2013). ${ }^{6}$ (Hollesen et al., 2011). ${ }^{7}$ (Rydén et al., 1980). ${ }^{8}$ (Roth and Boike, 2001). ${ }^{9}$ S. Zubrzycki, soil carbon data. ${ }^{10}$ PAGE21 catalogue of physical parameters. ${ }^{11}$ (Bartholomeus et al., 2012). ${ }^{12}$ (Elberling et al., 2008). In most cases soil types (see Sect. 2.3) were translated to approximate sand-silt-clay fractions using Table 1 in (Beringer et al., 2001). Topographic index is from a global dataset: a $0.5^{\circ}$ aggregate from US Geological Survey (2000).

\begin{tabular}{lrrrrr}
\hline & Abisko & Bayelva & Kytalyk & Samoylov & Zackenberg \\
\hline Organic layer thickness $(\mathrm{cm})$ & $\sim 50^{1}$ & $0^{2}$ & $\sim 20^{3,4}$ & $\sim 30^{5}$ & $5^{6}$ \\
Sand fraction & 0.1 & 0.17 & 0.17 & 0.58 & $0.8^{6}$ \\
Silt fraction & 0.9 & 0.7 & 0.7 & 0.32 & $0.1^{6}$ \\
Clay fraction & 0.0 & 0.13 & 0.13 & 0.1 & $0.1^{6}$ \\
Bulk density & $1.3^{7}$ & $1.7^{8}$ & $0.6^{4}$ & $0.8^{9}$ & $0.9-1.8^{10}$ \\
C below organic layer $\left(\mathrm{kg} \mathrm{m}^{-3}\right)$ & $14^{*}$ & $0^{*}$ & $17^{11 *}$ & $35^{9}$ & $10^{12}$ \\
Topographic index mean & 4.0 & 3.9 & 6.2 & 5.9 & 6.7 \\
Topographic index st.dev. & 2.5 & 1.6 & 2.8 & 2.2 & 1.2 \\
\hline
\end{tabular}

* Estimated from bulk density

Table A2. Soil layer thicknesses in the models.

\begin{tabular}{ll}
\hline Model & Layer thicknesses $(\mathrm{m})$ \\
\hline JSBACH & $0.06,0.26,0.92,2.88,5.72,13.2,30.1$ \\
JULES & $0.05,0.08,0.11,0.14,0.17,0.19,0.22,0.24,0.26,0.28,0.30,0.32,0.34,0.36,0.38,0.40$, \\
& $0.42,0.44,0.46,0.47,0.49,0.51,0.53,0.54,0.56,0.58,0.59,0.61$ \\
ORCHIDEE & $0.0005,0.002,0.01,0.01,0.03,0.06,0.12,0.25,0.50,1.00,1.75$ \\
hydrological & \\
ORCHIDEE & $0.0005,0.002,0.01,0.01,0.03,0.06,0.12,0.25,0.50,1.00,1.75,2.50,3.50,4.55,5.66$, \\
thermal & $6.81,8.03,9.31,10.65,12.06,13.54,15.09,16.72,18.43,20.23,22.12,24.10,26.18$, \\
& $28.37,30.66,33.07,35.60$ \\
\hline
\end{tabular}




\section{The Supplement related to this article is available online at https://doi.org/10.5194/bg-14-5143-2017-supplement.}

Competing interests. The authors declare that they have no conflict of interest.

Special issue statement. This article is part of the special issue "Changing Permafrost in the Arctic and its Global Effects in the 21st Century (PAGE21) (BG/ESSD/GMD/TC inter-journal SI)". It is not associated with a conference.

Acknowledgements. The authors acknowledge financial support by the European Union Seventh Framework Programme (FP7/20072013) project PAGE21, under GA282700. Sarah E. Chadburn, Sebastian Westermann and Gustaf Hugelius acknowledge support from COUP (Constraining uncertainties in permafrost-climate feedback) Joint Programming Initiative project (Sarah E. Chadburn: National Environment Research Council grant NE/M01990X/1; Gustaf Hugelius: Swedish Research Council grant no. E0689701; Sebastian Westermann: Research Council of Norway project no. 244903/E10). Data from Zackenberg were provided by the Greenland Ecosystem Monitoring Programme.

Edited by: Isabelle Laurion

Reviewed by: Florent Dominé and one anonymous referee

\section{References}

Abermann, J., Hansen, B., Lund, M., Wacker, S., Karami, M., and Cappelen, J.: Hotspots and key periods of Greenland climate change during the past six decades, Ambio, 46, 3-11, 2017.

Åkerman, H. J. and Johansson, M.: Thawing permafrost and thicker active layers in sub-arctic Sweden, Permafrost Periglac, 19, 279292, 2008.

Atkin, O. K.: Reassessing the nitrogen relations of Arctic plants: a mini-review, Plant Cell Environ., 19, 695-704, https://doi.org/10.1111/j.1365-3040.1996.tb00404.x, 1996.

Barr, A., Richardson, A., Hollinger, D., Papale, D., Arain, M., Black, T., Bohrer, G., Dragoni, D., Fischer, M., Gu, L., Law, B. E., Margolis, H. A., McCaughey, J. H., Munger, J. W., Oechel, W., and Schaeffer, K.: Use of change-point detection for frictionvelocity threshold evaluation in eddy-covariance studies, Agr. Forest Meteorol., 171, 31-45, 2013.

Bartholomeus, H., Schaepman-Strub, G., Blok, D., Sofronov, R., and Udaltsov, S.: Spectral estimation of soil properties in Siberian tundra soils and relations with plant species composition, Appl. Environ. Soil Sci., 2012, 241535, https://doi.org/10.1155/2012/241535, 2012.

Beer, C.: Permafrost sub-grid heterogeneity of soil properties key for 3-D soil processes and future climate projections, Front. Earth Sci., 4, 81, https://doi.org/10.3389/feart.2016.00081, 2016.

Beringer, J., Lynch, A. H., Chapin, F. S., Mack, M., and Bonan, G. B.: The Representation of Arctic Soils in the Land Surface Model: The Importance of Mosses, J. Clim., 14, 3324-3335, https://doi.org/10.1175/15200442(2001)014<3324:TROASI>2.0.CO;2, 2001.

Bernier, P., Desjardins, R., Karimi-Zindashty, Y., Worth, D., Beaudoin, A., Luo, Y., and Wang, S.: Boreal lichen woodlands: A possible negative feedback to climate change in eastern North America, Agr. Forest Meteorol., 151, 521-528, https://doi.org/10.1016/j.agrformet.2010.12.013, 2011.

Best, M. J., Pryor, M., Clark, D. B., Rooney, G. G., Essery, R. L. H., Ménard, C. B., Edwards, J. M., Hendry, M. A., Porson, A., Gedney, N., Mercado, L. M., Sitch, S., Blyth, E., Boucher, O., Cox, P. M., Grimmond, C. S. B., and Harding, R. J.: The Joint UK Land Environment Simulator (JULES), model description Part 1: Energy and water fluxes, Geosci. Model Dev., 4, 677-699, https://doi.org/10.5194/gmd-4-677-2011, 2011.

Boike, J., Roth, K., and Ippisch, O.: Seasonal snow cover on frozen ground: Energy balance calculations of a permafrost site near Ny-Ålesund, Spitsbergen, J. Geophys. Res.-Atmos., 108, 8163, https://doi.org/10.1029/2001JD000939, 2003.

Boike, J., Ippisch, O., Overduin, P. P., Hagedorn, B., and Roth, K.: Water, heat and solute dynamics of a mud boil, Spitsbergen, $\mathrm{Ge}-$ omorphology, 95, 61-73, 2008a.

Boike, J., Wille, C., and Abnizova, A.: Climatology and summer energy and water balance of polygonal tundra in the Lena River Delta, Siberia, J. Geophys. Res.-Biogeo., 113, G03025, https://doi.org/10.1029/2007JG000540, 2008b.

Boike, J., Kattenstroth, B., Abramova, K., Bornemann, N., Chetverova, A., Fedorova, I., Fröb, K., Grigoriev, M., Grüber, M., Kutzbach, L., Langer, M., Minke, M., Muster, S., Piel, K., Pfeiffer, E.-M., Stoof, G., Westermann, S., Wischnewski, K., Wille, C., and Hubberten, H.-W.: Baseline characteristics of climate, permafrost and land cover from a new permafrost observatory in the Lena River Delta, Siberia (1998-2011), Biogeosciences, 10, 2105-2128, https://doi.org/10.5194/bg-10-21052013, 2013.

Bouchard, F., Laurion, I., Prèskienis, V., Fortier, D., Xu, X., and Whiticar, M. J.: Modern to millennium-old greenhouse gases emitted from ponds and lakes of the Eastern Canadian Arctic (Bylot Island, Nunavut), Biogeosciences, 12, 7279-7298, https://doi.org/10.5194/bg-12-7279-2015, 2015.

Brovkin, V., Raddatz, T., Reick, C. H., Claussen, M., and Gayler, V.: Global biogeophysical interactions between forest and climate, Geophys. Res. Lett., 36, L07405, https://doi.org/10.1029/2009GL037543, 2009.

Brown, J., Ferrians Jr., O. J., Heginbottom, J., and Melnikov, E.: Circum-arctic map of permafrost and ground ice conditions, National Snow and Ice Data Center, http://nsidc.org/data/docs/fgdc/ ggd318_map_circumarctic (last access: 23 October 2017), 1998.

Burke, E. J., Hartley, I. P., and Jones, C. D.: Uncertainties in the global temperature change caused by carbon release from permafrost thawing, The Cryosphere, 6, 1063-1076, https://doi.org/10.5194/tc-6-1063-2012, 2012.

Burke, E. J., Jones, C. D., and Koven, C. D.: Estimating the permafrost-carbon climate response in the CMIP5 climate models using a simplified approach, J. Clim., 26, 4897-4909, 2013.

Burke, E. J., Chadburn, S. E., and Ekici, A.: A vertical representation of soil carbon in the JULES land surface scheme (vn4.3_permafrost) with a focus on permafrost regions, Geosci. 
Model Dev., 10, 959-975, https://doi.org/10.5194/gmd-10-9592017, 2017.

Cahoon, S. M. P., Sullivan, P. F., Shaver, G. R., Welker, J. M., and Post, E.: Interactions among shrub cover and the soil microclimate may determine future Arctic carbon budgets, Ecol. Lett., 15, 1415-1422, https://doi.org/10.1111/j.14610248.2012.01865.x, 2012.

Callaghan, T. V., Bergholm, F., Christensen, T. R., Jonasson, C., Kokfelt, U., and Johansson, M.: A new climate era in the sub-Arctic: Accelerating climate changes and multiple impacts, Geophys. Res. Lett., 37, L14705, https://doi.org/10.1029/2009GL042064, 2010.

Cannone, N., Augusti, A., Malfasi, F., Pallozzi, E., Calfapietra, C., and Brugnoli, E.: The interaction of biotic and abiotic factors at multiple spatial scales affects the variability of $\mathrm{CO}_{2}$ fluxes in polar environments, Polar Biol., 39, 1581-1596, 2016.

Chadburn, S., Burke, E., Essery, R., Boike, J., Langer, M., Heikenfeld, M., Cox, P., and Friedlingstein, P.: An improved representation of physical permafrost dynamics in the JULES land-surface model, Geosci. Model Dev., 8, 1493-1508, https://doi.org/10.5194/gmd-8-1493-2015, 2015a.

Chadburn, S. E., Burke, E. J., Essery, R. L. H., Boike, J., Langer, M., Heikenfeld, M., Cox, P. M., and Friedlingstein, P.: Impact of model developments on present and future simulations of permafrost in a global land-surface model, The Cryosphere, 9, 1505-1521, https://doi.org/10.5194/tc-9-1505-2015, 2015b.

Christiansen, H. H., Etzelmüller, B., Isaksen, K., Juliussen, H., Farbrot, H., Humlum, O., Johansson, M., Ingeman-Nielsen, T., Kristensen, L., Hjort, J., Holmlund, P., Sannel, A. B. K., Sigsgaard, C., Åkerman, H. J., Foged, N., Blikra, L. H., Pernosky, M. A., and Ødegård, R. S.: The thermal state of permafrost in the Nordic area during the International Polar Year 2007-2009, Permafrost Periglac., 21, 156-181, 2010

Clark, D. B., Mercado, L. M., Sitch, S., Jones, C. D., Gedney, N., Best, M. J., Pryor, M., Rooney, G. G., Essery, R. L. H., Blyth, E., Boucher, O., Harding, R. J., Huntingford, C., and Cox, P. M.: The Joint UK Land Environment Simulator (JULES), model description - Part 2: Carbon fluxes and vegetation dynamics, Geosci. Model Dev., 4, 701-722, https://doi.org/10.5194/gmd-4701-2011, 2011.

Cohen, W. B., Maiersperger, T. K., Turner, D. P., Ritts, W. D., Pflugmacher, D., Kennedy, R. E., Kirschbaum, A., Running, S. W., Costa, M., and Gower, S. T.: MODIS land cover and LAI collection 4 Product quality across nine sites in the western hemisphere, IEEE T. Geosci. Remote, 44, 1843-1857, 2006.

Cristóbal, J., Prakash, A., Anderson, M. C., Kustas, W. P., Euskirchen, E. S., and Kane, D. L.: Estimation of surface energy fluxes in the Arctic tundra using the remote sensing thermalbased Two-Source Energy Balance model, Hydrol. Earth Syst. Sci., 21, 1339-1358, https://doi.org/10.5194/hess-21-1339-2017, 2017.

Domine, F., Barrere, M., and Sarrazin, D.: Seasonal evolution of the effective thermal conductivity of the snow and the soil in high Arctic herb tundra at Bylot Island, Canada, The Cryosphere, 10, 2573-2588, https://doi.org/10.5194/tc-10-2573-2016, 2016.

Dyrness, C.: Control of depth to permafrost and soil temperature by the forest floor in black spruce/feathermoss communities, Pacific Northwest Forest and Range Experiment Station (Portland, Or.), 396 pp., 1982.
Ekici, A., Beer, C., Hagemann, S., Boike, J., Langer, M., and Hauck, C.: Simulating high-latitude permafrost regions by the JSBACH terrestrial ecosystem model, Geosci. Model Dev., 7, 631-647, https://doi.org/10.5194/gmd-7-631-2014, 2014.

Ekici, A., Chadburn, S., Chaudhary, N., Hajdu, L. H., Marmy, A., Peng, S., Boike, J., Burke, E., Friend, A. D., Hauck, C., Krinner, G., Langer, M., Miller, P. A., and Beer, C.: Site-level model intercomparison of high latitude and high altitude soil thermal dynamics in tundra and barren landscapes, The Cryosphere, 9, 1343-1361, https://doi.org/10.5194/tc-9-1343-2015, 2015.

Elberling, B., Tamstorf, M. P., Michelsen, A., Arndal, M. F., Sigsgaard, C., Illeris, L., Bay, C., Hansen, B. U., Christensen, T. R., Hansen, E. S., Jakobsen, B. H., and Beyens, L.: Soil and plant community-characteristics and dynamics at Zackenberg, Adv. Ecol. Res., 40, 223-248, 2008.

Elberling, B., Michelsen, A., Schädel, C., Schuur, E. A., Christiansen, H. H., Berg, L., Tamstorf, M. P., and Sigsgaard, C.: Long-term $\mathrm{CO}_{2}$ production following permafrost thaw, Nature Climate Change, 3, 890-894, 2013.

Epstein, H., Bhatt, U., Raynolds, M., Walker, D., Forbes, B., Macias-Fauria, M., Loranty, M., Phoenix, G., and Bjerke, J.: Tundra Greenness, www.arctic.noaa.gov/reportcard (last access: 13 October 2017), p. 59, 2016.

Boike, J., Juszak, I., Lange, S., Chadburn, S., Burke, E., Overduin, P. P., Roth, K., Ippisch, O., Bornemann, N., Stern, L., Gouttevin, I., Hauber, E., and Westermann, S.: A 20-year record (19982017) of permafrost, active layer, and meteorological conditions at a High Arctic permafrost research site (Bayelva, Spitsbergen): an opportunity to validate remote sensing data and land surface, snow, and permafrost models, Earth Syst. Sci. Data Discuss., https://doi.org/10.5194/essd-2017-100, in review, 2017.

Fedorova, I., Chetverova, A., Bolshiyanov, D., Makarov, A., Boike, J., Heim, B., Morgenstern, A., Overduin, P. P., Wegner, C., Kashina, V., Eulenburg, A., Dobrotina, E., and Sidorina, I.: Lena Delta hydrology and geochemistry: long-term hydrological data and recent field observations, Biogeosciences, 12, 345-363, https://doi.org/10.5194/bg-12-345-2015, 2015.

Frolking, S., Roulet, N. T., Tuittila, E., Bubier, J. L., Quillet, A., Talbot, J., and Richard, P. J. H.: A new model of Holocene peatland net primary production, decomposition, water balance, and peat accumulation, Earth Syst. Dynam., 1, 1-21, https://doi.org/10.5194/esd-1-1-2010, 2010.

Frost, G. V. and Epstein, H. E.: Tall shrub and tree expansion in Siberian tundra ecotones since the 1960s, Glob. Change Biol., 20, 1264-1277, https://doi.org/10.1111/gcb.12406, 2014.

Gedney, N. and Cox, P. M.: The Sensitivity of Global Climate Model Simulations to the Representation of Soil Moisture, J. Hydrometeorol., 4, 1265-1275, https://doi.org/10.1175/15257541(2003)004<1265:TSOGCM>2.0.CO;2, 2003.

Goll, D. S., Brovkin, V., Liski, J., Raddatz, T., Thum, T., and ToddBrown, K. E.: Strong dependence of $\mathrm{CO}_{2}$ emissions from anthropogenic land cover change on initial land cover and soil carbon parametrization, Global Biogeochem. Cy., 29, 1511-1523, 2015.

Gouttevin, I., Krinner, G., Ciais, P., Polcher, J., and Legout, C.: Multi-scale validation of a new soil freezing scheme for a landsurface model with physically-based hydrology, The Cryosphere, 6, 407-430, https://doi.org/10.5194/tc-6-407-2012, 2012a.

Gouttevin, I., Menegoz, M., Dominé, F., Krinner, G., Koven, C., Ciais, P., Tarnocai, C., and Boike, J.: How the insulating prop- 
erties of snow affect soil carbon distribution in the continental pan-Arctic area, J. Geophys. Res.-Biogeo., 117, G02020, https://doi.org/10.1029/2011JG001916, 2012b.

Guimberteau, M., Zhu, D., Maignan, F., Huang, Y., Yue, C., DantecNédélec, S., Ottlé, C., Jornet-Puig, A., Bastos, A., Laurent, P., Goll, D., Bowring, S., Chang, J., Guenet, B., Tifafi, M., Peng, S., Krinner, G., Ducharne, A., Wang, F., Wang, T., Wang, X., Wang, Y., Yin, Z., Lauerwald, R., Joetzjer, E., Qiu, C., Kim, H., and Ciais, P.: ORCHIDEE-MICT (revision 4126), a land surface model for the high-latitudes: model description and validation, Geosci. Model Dev. Discuss., https://doi.org/10.5194/gmd-2017122, in review, 2017.

Hagemann, S. and Stacke, T.: Impact of the soil hydrology scheme on simulated soil moisture memory, Clim. Dynam., 44, 1731$1750,2015$.

Harper, A. B., Cox, P. M., Friedlingstein, P., Wiltshire, A. J., Jones, C. D., Sitch, S., Mercado, L. M., Groenendijk, M., Robertson, E., Kattge, J., Bönisch, G., Atkin, O. K., Bahn, M., Cornelissen, J., Niinemets, U., Onipchenko, V., Peñuelas, J., Poorter, L., Reich, P. B., Soudzilovskaia, N. A., and Bodegom, P. V.: Improved representation of plant functional types and physiology in the Joint UK Land Environment Simulator (JULES v4.2) using plant trait information, Geosci. Model Dev., 9, 2415-2440, https://doi.org/10.5194/gmd-9-2415-2016, 2016.

Hayes, D. J., McGuire, A. D., Kicklighter, D. W., Gurney, K. R., Burnside, T. J., and Melillo, J. M.: Is the northern high-latitude land-based $\mathrm{CO}_{2}$ sink weakening?, Global Biogeochem. Cy., 25, GB3018, https://doi.org/10.1029/2010GB003813, 2011.

Hollesen, J., Elberling, B., and Jansson, P.-E.: Future active layer dynamics and carbon dioxide production from thawing permafrost layers in Northeast Greenland, Glob. Change Biol., 17, 911-926, 2011.

Hugelius, G., Strauss, J., Zubrzycki, S., Harden, J. W., Schuur, E. A. G., Ping, C.-L., Schirrmeister, L., Grosse, G., Michaelson, G. J., Koven, C. D., O’Donnell, J. A., Elberling, B., Mishra, U., Camill, P., Yu, Z., Palmtag, J., and Kuhry, P.: Estimated stocks of circumpolar permafrost carbon with quantified uncertainty ranges and identified data gaps, Biogeosciences, 11, 6573-6593, https://doi.org/10.5194/bg-11-6573-2014, 2014.

Jammet, M., Crill, P., Dengel, S., and Friborg, T.: Large methane emissions from a subarctic lake during spring thaw: Mechanisms and landscape significance, J. Geophys. Res.-Biogeo., 120, 2289-2305, 2015.

Jammet, M., Dengel, S., Kettner, E., Parmentier, F.-J. W., Wik, M., Crill, P., and Friborg, T.: Year-round $\mathrm{CH}_{4}$ and $\mathrm{CO}_{2}$ flux dynamics in two contrasting freshwater ecosystems of the subarctic, Biogeosciences Discuss., https://doi.org/10.5194/bg-2016466, in review, 2017

Johansson, M., Christensen, T. R., Akerman, H. J., and Callaghan, T. V.: What determines the current presence or absence of permafrost in the Torneträsk Region, a sub-Arctic landscape in Northern Sweden?, AMBIO, 35, 190-197, 2006.

Johansson, M., Åkerman, J., Keuper, F., Christensen, T. R., Lantuit, H., and Callaghan, T. V.: Past and present permafrost temperatures in the Abisko area: Redrilling of boreholes, Ambio, 40, 558-565, 2011.

Johansson, M., Callaghan, T. V., Bosiö, J., Åkerman, H. J., Jackowicz-Korczynski, M., and Christensen, T. R.: Rapid responses of permafrost and vegetation to experimentally increased snow cover in sub-arctic Sweden, Environ. Res. Lett., 8, 035025, https://doi.org/10.1088/1748-9326/8/3/035025, 2013.

Kaiser, S., Göckede, M., Castro-Morales, K., Knoblauch, C., Ekici, A., Kleinen, T., Zubrzycki, S., Sachs, T., Wille, C., and Beer, C.: Process-based modelling of the methane balance in periglacial landscapes (JSBACH-methane), Geosci. Model Dev., 10, 333 358, https://doi.org/10.5194/gmd-10-333-2017, 2017.

Klaminder, J., Yoo, K., Rydberg, J., and Giesler, R.: An explorative study of mercury export from a thawing palsa mire, J. Geophys. Res.-Biogeo., 113, G04034, https://doi.org/10.1029/2008JG000776, 2008.

Knorr, W.: Annual and interannual $\mathrm{CO}_{2}$ exchanges of the terrestrial biosphere: Process-based simulations and uncertainties, Global Ecol. Biogeogr., 9, 225-252, 2000.

Koven, C., Friedlingstein, P., Ciais, P., Khvorostyanov, D., Krinner, G., and Tarnocai, C.: On the formation of high-latitude soil carbon stocks: Effects of cryoturbation and insulation by organic matter in a land surface model, Geophys. Res. Lett., 36, L21501, https://doi.org/10.1029/2009GL040150, 2009.

Koven, C. D., Riley, W. J., Subin, Z. M., Tang, J. Y., Torn, M. S., Collins, W. D., Bonan, G. B., Lawrence, D. M., and Swenson, S. C.: The effect of vertically resolved soil biogeochemistry and alternate soil $\mathrm{C}$ and $\mathrm{N}$ models on C dynamics of CLM4, Biogeosciences, 10, 7109-7131, https://doi.org/10.5194/bg-107109-2013, 2013.

Koven, C. D., Schuur, E., Schädel, C., Bohn, T., Burke, E., Chen, G., Chen, X., Ciais, P., Grosse, G., Harden, J. W., Hayes, D. J., Hugelius, G., E. Jafarov, E., Krinner, G., Kuhry, P., Lawrence, D. M., MacDougall, A. H., Marchenko, S. S., McGuire, A. D., Natali, S. M., Nicolsky, D. J., Olefeldt, D., Peng, S., Romanovsky, V. E., Schaefer, K. M., Strauss, J., Treat, C. C., and Turetsky, M.: A simplified, data-constrained approach to estimate the permafrost carbon-climate feedback, Phil. Trans. R. Soc. A, 373, 20140423, https://doi.org/10.1098/rsta.2014.0423, 2015.

Krinner, G., Viovy, N., de Noblet-Ducoudré, N., Ogée, J., Polcher, J., Friedlingstein, P., Ciais, P., Sitch, S., and Prentice, I. C.: A dynamic global vegetation model for studies of the coupled atmosphere-biosphere system, Global Biogeochem. Cy., 19, GB1015, https://doi.org/10.1029/2003GB002199, 2005.

Kutzbach, L., Wille, C., and Pfeiffer, E.-M.: The exchange of carbon dioxide between wet arctic tundra and the atmosphere at the Lena River Delta, Northern Siberia, Biogeosciences, 4, 869-890, https://doi.org/10.5194/bg-4-869-2007, 2007.

Langer, M., Westermann, S., Muster, S., Piel, K., and Boike, J.: The surface energy balance of a polygonal tundra site in northern Siberia - Part 1: Spring to fall, The Cryosphere, 5, 151-171, https://doi.org/10.5194/tc-5-151-2011, 2011a.

Langer, M., Westermann, S., Muster, S., Piel, K., and Boike, J.: The surface energy balance of a polygonal tundra site in northern Siberia - Part 2: Winter, The Cryosphere, 5, 509-524, https://doi.org/10.5194/tc-5-509-2011, 2011b.

Langer, M., Westermann, S., Walter Anthony, K., Wischnewski, K., and Boike, J.: Frozen ponds: production and storage of methane during the Arctic winter in a lowland tundra landscape in northern Siberia, Lena River delta, Biogeosciences, 12, 977-990, https://doi.org/10.5194/bg-12-977-2015, 2015.

Lasslop, G., Reichstein, M., Papale, D., Richardson, A. D., Arneth, A., Barr, A., Stoy, P., and Wohlfahrt, G.: Separation of net ecosystem exchange into assimilation and respiration using 
a light response curve approach: critical issues and global evaluation, Glob. Change Biol., 16, 187-208, 2010.

Lawrence, D. and Slater, A.: Incorporating organic soil into a global climate model, Clim. Dynam., 30, 145-160, https://doi.org/10.1007/s00382-007-0278-1, 2008.

López-Moreno, J., Boike, J., Sanchez-Lorenzo, A., and Pomeroy, J.: Impact of climate warming on snow processes in Ny-Ålesund, a polar maritime site at Svalbard, Glob. Planet. Change, 146, 1021, 2016.

Lüers, J., Westermann, S., Piel, K., and Boike, J.: Annual $\mathrm{CO}_{2}$ budget and seasonal $\mathrm{CO}_{2}$ exchange signals at a high Arctic permafrost site on Spitsbergen, Svalbard archipelago, Biogeosciences, 11, 6307-6322, https://doi.org/10.5194/bg-11-63072014, 2014.

Lund, M., Falk, J. M., Friborg, T., Mbufong, H. N., Sigsgaard, C., Soegaard, H., and Tamstorf, M. P.: Trends in $\mathrm{CO}_{2}$ exchange in a high Arctic tundra heath, 2000-2010, J. Geophys. Res.-Biogeo., 117, G02001, https://doi.org/10.1029/2011JG001901, 2012.

Lund, M., Hansen, B. U., Pedersen, S. H., Stiegler, C., and Tamstorf, M. P.: Characteristics of summer-time energy exchange in a high Arctic tundra heath 2000-2010, Tellus B, 66, 21631, https://doi.org/10.3402/tellusb.v66.21631, 2014.

Lund, M., Stiegler, C., Abermann, J., Citterio, M., Hansen, B. U., and van As, D.: Spatiotemporal variability in surface energy balance across tundra, snow and ice in Greenland, Ambio, 46, 8193, 2017.

MacDougall, A. H. and Knutti, R.: Projecting the release of carbon from permafrost soils using a perturbed parameter ensemble modelling approach, Biogeosciences, 13, 2123-2136, https://doi.org/10.5194/bg-13-2123-2016, 2016.

Marcott, S. A., Shakun, J. D., Clark, P. U., and Mix, A. C.: A reconstruction of regional and global temperature for the past 11,300 years, Science, 339, 1198-1201, 2013.

Mastepanov, M., Sigsgaard, C., Dlugokencky, E. J., Houweling, S., Ström, L., Tamstorf, M. P., and Christensen, T. R.: Large tundra methane burst during onset of freezing, Nature, 456, 628-630, 2008.

Mastepanov, M., Sigsgaard, C., Tagesson, T., Ström, L., Tamstorf, M. P., Lund, M., and Christensen, T. R.: Revisiting factors controlling methane emissions from high-Arctic tundra, Biogeosciences, 10, 5139-5158, https://doi.org/10.5194/bg-105139-2013, 2013.

Meinshausen, M., Smith, S. J., Calvin, K., Daniel, J. S., Kainuma, M. L. T., Lamarque, J.-F., Matsumoto, K., Montzka, S. A., Raper, S. C. B., Riahi, K., Thomson, A., Velders, G. J. M., and van Vuuren, D. P.: The RCP greenhouse gas concentrations and their extensions from 1765 to 2300, Climatic Change, 109, 213-241, https://doi.org/10.1007/s10584-011-0156-z, 2011.

MODIS15A2: NASA EOSDIS Land Processes DAAC, USGS Earth Resources Observation and Science (EROS) Center, Sioux Falls, South Dakota (https://lpdaac.usgs.gov), last access: 13 December 2016.

Morgenstern, A., Ulrich, M., Günther, F., Roessler, S., Fedorova, I. V., Rudaya, N. A., Wetterich, S., Boike, J., and Schirrmeister, L.: Evolution of thermokarst in East Siberian ice-rich permafrost: A case study, Geomorphology, 201, 363-379, 2013.

Ohtsuka, T., Adachi, M., Uchida, M., and Nakatsubo, T.: Relationships between vegetation types and soil properties along a topo- graphical gradient on the northern coast of the Brgger Peninsula, Svalbard, Polar Bioscience, 19, 63-72, 2006.

Palmer, K., Biasi, C., and Horn, M. A.: Contrasting denitrifier communities relate to contrasting $\mathrm{N}_{2} \mathrm{O}$ emission patterns from acidic peat soils in arctic tundra, ISME J., 6, 1058-1077, 2012.

Palmtag, J., Hugelius, G., Lashchinskiy, N., Tamstorf, M. P., Richter, A., Elberling, B., and Kuhry, P.: Storage, Landscape Distribution, and Burial History of Soil Organic Matter in Contrasting Areas of Continuous Permafrost, Arct. Antarct. Alp. Res., 47, 71-88, https://doi.org/10.1657/AAAR0014-027, 2015.

Papale, D., Reichstein, M., Aubinet, M., Canfora, E., Bernhofer, C., Kutsch, W., Longdoz, B., Rambal, S., Valentini, R., Vesala, T., and Yakir, D.: Towards a standardized processing of Net Ecosystem Exchange measured with eddy covariance technique: algorithms and uncertainty estimation, Biogeosciences, 3, 571-583, https://doi.org/10.5194/bg-3-571-2006, 2006.

Parmentier, F., Van Der Molen, M., Van Huissteden, J., Karsanaev, S., Kononov, A., Suzdalov, D., Maximov, T., and Dolman, A. Longer growing seasons do not increase net carbon uptake in the northeastern Siberian tundra, J. Geophys. Res.-Biogeo., 116, G04013, https://doi.org/10.1029/2011JG001653, 2011.

Pedersen, E., Elberling, B., and Michelsen, A.: Seasonal variations in methane fluxes in response to summer warming and leaf litter addition in a subarctic heath ecosystem, J. Geophys. Res.Biogeo., 122, 2137-2153, 2017.

Pedersen, S. H., Tamstorf, M. P., Abermann, J., WestergaardNielsen, A., Lund, M., Skov, K., Sigsgaard, C., Mylius, M. R., Hansen, B. U., Liston, G. E., and Schmidt, N. M.: Spatiotemporal characteristics of seasonal snow cover in Northeast Greenland from in situ observations, Arct. Antarct. Alp. Res., 48, 653-671, 2016.

Peters, G. P., Andrew, R. M., Solomon, S., and Friedlingstein, P.: Measuring a fair and ambitious climate agreement using cumulative emissions, Environ. Res. Lett., 10, 105004 https://doi.org/10.1088/1748-9326/10/10/105004, 2015.

Pirk, N., Sievers, J., Mertes, J., Parmentier, F.-J. W., Mastepanov, M., and Christensen, T. R.: Spatial variability of $\mathrm{CO}_{2}$ uptake in polygonal tundra: assessing low-frequency disturbances in eddy covariance flux estimates, Biogeosciences, 14, 3157-3169, https://doi.org/10.5194/bg-14-3157-2017, 2017.

Porada, P., Weber, B., Elbert, W., Pöschl, U., and Kleidon, A.: Estimating global carbon uptake by lichens and bryophytes with a process-based model, Biogeosciences, 10, 6989-7033, https://doi.org/10.5194/bg-10-6989-2013, 2013.

Porada, P., Ekici, A., and Beer, C.: Effects of bryophyte and lichen cover on permafrost soil temperature at large scale, The Cryosphere, 10, 2291-2315, https://doi.org/10.5194/tc-10-22912016, 2016.

Qian, H., Joseph, R., and Zeng, N.: Enhanced terrestrial carbon uptake in the Northern High Latitudes in the 21st century from the Coupled Carbon Cycle Climate Model Intercomparison Project model projections, Glob. Change Biol., 16, 641-656, https://doi.org/10.1111/j.1365-2486.2009.01989.x, 2010.

Quegan, S., Beer, C., Shvidenko, A., McCallum, I., Handoh, I. C., Peylin, P., Roedenbeck, C., Lucht, W., Nilsson, S., and Schmullius, C.: Estimating the carbon balance of central Siberia using a landscape-ecosystem approach, atmospheric inversion and Dynamic Global Vegetation Models, Glob. Change Biol., 17, 351365, 2011. 
Raddatz, T., Reick, C., Knorr, W., Kattge, J., Roeckner, E., Schnur, R., Schnitzler, K.-G., Wetzel, P., and Jungclaus, J.: Will the tropical land biosphere dominate the climate-carbon cycle feedback during the twenty-first century?, Clim. Dynam., 29, 565-574, 2007.

Reichstein, M., Falge, E., Baldocchi, D., Papale, D., Aubinet, M., Berbigier, P., Bernhofer, C., Buchmann, N., Gilmanov, T., Granier, A., Grünwald, T., Havránková, K., Ilvesniemi, H., Janous, D., Knohl, A., Laurila, T., Lohila, A., Loustau, D., Matteucci, G., Meyers, T., Miglietta, F., Ourcival, J.-M., Pumpanen, J., Rambal, S., Rotenberg, E., Sanz, M., Tenhunen, J., Seufert, G., Vaccari, F., Vesala, T., Yakir, D., and Valentini, R.: On the separation of net ecosystem exchange into assimilation and ecosystem respiration: review and improved algorithm, Glob. Change Biol., 11, 1424-1439, 2005.

Ridefelt, H., Etzelmüller, B., Boelhouwers, J., and Jonasson, C.: Statistic-empirical modelling of mountain permafrost distribution in the Abisko region, sub-Arctic northern Sweden, Norsk. Geogr. Tidsskr, 62, 278-289, 2008.

Roth, K. and Boike, J.: Quantifying the thermal dynamics of a permafrost site near Ny-Ålesund, Svalbard, Water Resour. Res., 37 , 2901-2914, 2001.

Rowland, J. C. and Coon, E. T.: From documentation to prediction: raising the bar for thermokarst research, Hydrogeol. J., 24, 645648, 2015.

Rydén, B., Fors, L., and Kostov, L.: Physical properties of the tundra soil-water system at Stordalen, Abisko, Ecol. Bull., 30, 27-54, 1980.

Schaphoff, S., Heyder, U., Ostberg, S., Gerten, D., Heinke, J., and Lucht, W.: Contribution of permafrost soils to the global carbon budget, Environ. Res. Lett., 8, 014026, https://doi.org/10.1088/1748-9326/8/1/014026, 2013.

Schneider von Deimling, T., Meinshausen, M., Levermann, A., Huber, V., Frieler, K., Lawrence, D. M., and Brovkin, V.: Estimating the near-surface permafrost-carbon feedback on global warming, Biogeosciences, 9, 649-665, https://doi.org/10.5194/bg-9649-2012, 2012.

Schneider von Deimling, T., Grosse, G., Strauss, J., Schirrmeister, L., Morgenstern, A., Schaphoff, S., Meinshausen, M., and Boike, J.: Observation-based modelling of permafrost carbon fluxes with accounting for deep carbon deposits and thermokarst activity, Biogeosciences, 12, 3469-3488, https://doi.org/10.5194/bg12-3469-2015, 2015.

Schuldt, R. J., Brovkin, V., Kleinen, T., and Winderlich, J.: Modelling Holocene carbon accumulation and methane emissions of boreal wetlands - an Earth system model approach, Biogeosciences, 10, 1659-1674, https://doi.org/10.5194/bg-10-16592013, 2013.

Schuur, E. A. G., McGuire, A. D., Schadel, C., Grosse, G., Harden, J. W., Hayes, D. J., Hugelius, G., Koven, C. D., Kuhry, P., Lawrence, D. M., Natali, S. M., Olefeldt, D., Romanovsky, V. E., Schaefer, K., Turetsky, M. R., Treat, C. C., and Vonk, J. E.: Climate change and the permafrost carbon feedback, Nature, 520, 171-179, https://doi.org/10.1038/nature14338, 2015.

Siewert, M. B., Hanisch, J., Weiss, N., Kuhry, P., Maximov, T. C., and Hugelius, G.: Comparing carbon storage of Siberian tundra and taiga permafrost ecosystems at very high spatial resolution, J. Geophys. Res.-Biogeo., 120, 1973-1994, https://doi.org/10.1002/2015JG002999, 2015.
Siewert, M. B., Hugelius, G., Heim, B., and Faucherre, S.: Landscape controls and vertical variability of soil organic carbon storage in permafrost-affected soils of the Lena River Delta, Catena, 147, 725-741, 2016.

Stiegler, C., Lund, M., Christensen, T. R., Mastepanov, M., and Lindroth, A.: Two years with extreme and little snowfall: effects on energy partitioning and surface energy exchange in a high-Arctic tundra ecosystem, The Cryosphere, 10, 1395-1413, https://doi.org/10.5194/tc-10-1395-2016, 2016.

Sturm, M., Holmgren, J., McFadden, J. P., Liston, G. E., Chapin III, F. S., and Racine, C. H.: Snow-shrub interactions in Arctic tundra: a hypothesis with climatic implications, J. Clim., 14, 336344, 2001.

Tape, K., Sturm, M., and Racine, C.: The evidence for shrub expansion in Northern Alaska and the Pan-Arctic, Glob. Change Biol., 12, 686-702, https://doi.org/10.1111/j.1365-2486.2006.01128.x, 2006.

Tucker, C. J., Slayback, D. A., Pinzon, J. E., Los, S. O., Myneni, R. B., and Taylor, M. G.: Higher northern latitude normalized difference vegetation index and growing season trends from 1982 to 1999 , Int. J. Biometeorol., 45, 184-190, https://doi.org/10.1007/s00484-001-0109-8, 2001.

Uchida, M., Nakatsubo, T., Kanda, H., and Koizumi, H.: Estimation of the annual primary production of the lichen Cetrariella delisei in a glacier foreland in the High Arctic, Ny-Ålesund, Svalbard, Polar Res., 25, 39-49, 2006.

Uchida, M., Kishimoto, A., Muraoka, H., Nakatsubo, T., Kanda, H., and Koizumi, H.: Seasonal shift in factors controlling net ecosystem production in a high Arctic terrestrial ecosystem, J. Plant Res., 123, 79-85, 2009.

US Geological Survey: HYDRO1k Elevation derivative database, US Geological Survey Earth Resources Observation and Science (EROS) Center, Sioux Falls, South Dakota, https://lta.cr.usgs. gov/HYDRO1K (last access: 13 October 2017), 2000.

van der Molen, M. K., van Huissteden, J., Parmentier, F. J. W., Petrescu, A. M. R., Dolman, A. J., Maximov, T. C., Kononov, A. V. ., Karsanaev, S. V., and Suzdalov, D. A.: The growing season greenhouse gas balance of a continental tundra site in the Indigirka lowlands, NE Siberia, Biogeosciences, 4, 985-1003, https://doi.org/10.5194/bg-4-985-2007, 2007.

Van Huissteden, J., Maximov, T., and Dolman, A.: High methane flux from an arctic floodplain (Indigirka lowlands, eastern Siberia), J. Geophys. Res.-Biogeo., 110, G02002, https://doi.org/10.1029/2005JG000010, 2005.

Van Wijk, M. T., Williams, M., Laundre, J., and Shaver, G.: Interannual variability of plant phenology in tussock tundra: modelling interactions of plant productivity, plant phenology, snowmelt and soil thaw, Glob. Change Biol., 9, 743-758, https://doi.org/10.1046/j.1365-2486.2003.00625.x, 2003.

Wang, T., Ottlé, C., Boone, A., Ciais, P., Brun, E., Morin, S., Krinner, G., Piao, S., and Peng, S.: Evaluation of an improved intermediate complexity snow scheme in the ORCHIDEE land surface model, J. Geophys. Res.-Atmos., 118, 6064-6079, https://doi.org/10.1002/jgrd.50395, 2013.

Weedon, G. P.: Readme file for the "WFDEI" dataset, http://www. eu-watch.org/gfx_content/documents/README-WFDEI.pdf (last access: 13 October 2017), 2013.

Weedon, G. P., Gomes, S., Viterbo, P., Shuttleworth, W. J., Blyth, E., Österle, H., Adam, J. C., Bellouin, N., Boucher, O., and 
Best, M.: Creation of the WATCH forcing data and its use to assess global and regional reference crop evaporation over land during the twentieth century, J. Hydrometeorol., 12, 823-847, https://doi.org/10.1175/2011JHM1369.1, 2011.

Westermann, S., Lüers, J., Langer, M., Piel, K., and Boike, J.: The annual surface energy budget of a high-arctic permafrost site on Svalbard, Norway, The Cryosphere, 3, 245-263, https://doi.org/10.5194/tc-3-245-2009, 2009.

Westermann, S., Wollschläger, U., and Boike, J.: Monitoring of active layer dynamics at a permafrost site on Svalbard using multichannel ground-penetrating radar, The Cryosphere, 4, 475-487, https://doi.org/10.5194/tc-4-475-2010, 2010.

Westermann, S., Boike, J., Langer, M., Schuler, T. V., and Etzelmüller, B.: Modeling the impact of wintertime rain events on the thermal regime of permafrost, The Cryosphere, 5, 945-959, https://doi.org/10.5194/tc-5-945-2011, 2011.

Westermann, S., Elberling, B., Højlund Pedersen, S., Stendel, M., Hansen, B. U., and Liston, G. E.: Future permafrost conditions along environmental gradients in Zackenberg, Greenland, The Cryosphere, 9, 719-735, https://doi.org/10.5194/tc-9-719-2015, 2015.

Wieder, W. R., Bonan, G. B., and Allison, S. D.: Global soil carbon projections are improved by modelling microbial processes, Nature Climate Change, 3, 909-912, 2013.

Wieder, W. R., Cleveland, C. C., Smith, W. K., and Todd-Brown, K.: Future productivity and carbon storage limited by terrestrial nutrient availability, Nat. Geosci., 8, 441-444, 2015.
Xenakis, G. and Williams, M.: Comparing microbial and chemical kinetics for modelling soil organic carbon decomposition using the DecoChem v1.0 and DecoBio v1.0 models, Geosci. Model Dev., 7, 1519-1533, https://doi.org/10.5194/gmd-7-1519-2014, 2014.

Yang, D., Kane, D., Zhang, Z., Legates, D., and Goodison, B.: Bias corrections of long-term (1973-2004) daily precipitation data over the northern regions, Geophys. Res. Lett., 32, L19501, https://doi.org/10.1029/2005GL024057, 2005.

Yu, Z., Loisel, J., Brosseau, D. P., Beilman, D. W., and Hunt, S. J.: Global peatland dynamics since the Last Glacial Maximum, Geophys. Res. Lett., 37, L13402, https://doi.org/10.1029/2010GL043584, 2010.

Yuan, W., Liu, S., Dong, W., Liang, S., Zhao, S., Chen, J., Xu, W., Li, X., Barr, A., Black, T. A., Wende Yan, Goulden, M. L., Kulmala, L., Lindroth, A., Margolis, H. A., Matsuura, Y., Moors, E., van der Molen, M., Ohta, T., Pilegaard, K., Varlagin, A., and Vesala, T.: Differentiating moss from higher plants is critical in studying the carbon cycle of the boreal biome, Nat. Commun., 5, 4270, https://doi.org/10.1038/ncomms5270, 2014.

Zhu, D., Peng, S., Ciais, P., Zech, R., Krinner, G., Zimov, S., and Grosse, G.: Simulating soil organic carbon in yedoma deposits during the Last Glacial Maximum in a land surface model, Geophys. Res. Lett., 43, 5133-5142, 2016. 